\title{
Bir yerlileştirme örneği: Friedrich von Schiller'e ait "Die Bürgschaft” adlı baladın Ali Bey Hüseyinzâde (Turan) tarafından Türkçeye çevirisi
}

\section{Alaattin UCA 1}

\section{Firat SOYSAL2}

\begin{abstract}
APA: Uca, A.; Soysal, F. (2020). Bir yerlileştirme örneği: Friedrich von Schiller'e ait "Die Bürgschaft" adlı baladın Ali Bey Hüseyinzâde (Turan) tarafindan Türkçeye çevirisi. RumeliDE Dil ve Edebiyat Araştırmaları Dergisi, (20), 784-815. DOI: 10.29000/rumelide.792507.
\end{abstract}

$\ddot{O} z$

Bu çalışmada Friedrich von Schiller’in "Die Bürgschaft” adlı baladının Ali Bey Hüzeyinzâde (Turan) tarafından Türkçeye aktarılmış olan ve 1923 yılına tarihlendirilebilen "Kefalet Yahud Vefadar Dost(lar)” adlı çevirisi, çeviride yerlileştirme stratejisi bakımından ele alınmaktadır. Ayrıca günümüz Türk Diline daha yakın bir söylem ve üslup kullanılarak aynı baladın alternatif bir çevirisi de gerçekleştirilmiştir. Hüseyinzâde Turan'ın, çevirisinde bilinçli veya bilinçsiz olarak yerlileştirme stratejisini uygulamış olduğu görülebilmektedir. Gerek çeviride yerlileştirme stratejisine uygun bir örnek olması gerekse Schiller'in "Die Bürgschaft" baladının ilk çevirisi olma iddiasından dolayı Hüseyinzâde Turan'ın çevirisi örnek erek metin olarak bu çalışma için seçilmiştir. Çalışmanın içerisinde kaynak ve erek metin ve çevirmen hakkında bilgi verilmekte, kuramsal açıdan ise çeviride yerlileştirme stratejisine ve Balat edebi türüne ilişkin açılamalarda bulunulmaktadır. Eldeki metinlere çalışmada aynen yer verildikten sonra kaynak metinden, erek metinden ve sunulan alternatif çeviri metinden alınan örnekler üzerinde bir inceleme (analiz) yapılmaktadır. Söz konusu inceleme sayesinde örnekler aracılığıyla çeviride yer alan yerlileştirici unsurlar gösterilmekte, çeviri süreci ve eşdeğerliği açısından bu durum irdelenmektedir. Elde edilen çıkarımlar ise örnekler altında detaylı bir biçimde tartışılmaktadır. Değerlendirme kısmında örnek erek metinde tespit edilen çeviride yerlileştirici unsurların daha ziyade hangi alanları ve/veya terminolojileri kapsadı̆̆ı vurgulanmaktadır. Sonuç ve önerilere yine bu kısımda yer verilmektedir.

Anahtar kelimeler: Die Bürgschaft, Ali Bey Hüseyinzade Turan, Yerlileştirme Stratejisi, Çeviri İncelemesi, Balat

\section{An exemplification of domestication: Translation of Friedrich von Schiller's ballad "Die Bürgschaft" into Turkish by Ali Bey Hüseyinzâde (Turan)}

\begin{abstract}
The translation of Friedrich von Schiller's ballad named "Die Bürgschaft" into Turkish by Ali Bey Hüzeyinzâde (Turan), dated to 1923, is discussed in the current study in terms of the domestication strategy. In addition, an alternative translation of the above-mentioned ballad has been made by using a familiar discourse and style to the usage of today's Turkish Language. In Hüseyinzâde Turan's

Doç. Dr. Karamanoğlu Mehmetbey Üniversitesi, Edebiyat Fakültesi, Tarih Bölümü (Karaman, Türkiye), alaattinuca@kmu.edu.tr, ORCID ID: oooo-0002-4211-6744 [Makale kayıt tarihi: 07.08.2020-kabul tarihi: 20.09.2020; DOI: $10.29000 /$ rumelide.792507]

2 Doktora öğrencisi, Sakarya Üniversitesi, Sosyal Bilimler Enstitüsü, Çeviribilim ABD (Sakarya, Türkiye), firat.soysal@ogr.sakarya.edu.tr / Arş. Gör., Karamanoğlu Mehmetbey Üniversitesi, Yabancı Diller Yüksekokulu, Mütercim ve Tercümanlık Bölümü (Almanca Mütercim ve Tercümanlık ABD) (Karaman, Türkiye), fsoysal@kmu.edu.tr, ORCID ID: o000-0001-7682-0812
\end{abstract}


translation, it can be presumed that he has applied the domestication strategy consciously or unconsciously. His translation has been chosen for this study because of the fact that it is a suitable example for the domestication strategy in translation and due to the argument that it is the first Turkish translation of Schiller's ballad "Die Bürgschaft". In the study information is given about the source and the target texts and also about the translator. Moreover, some explanations are made theoretically on the domestication strategy in translation and the Ballad as a literary genre. After the original texts are literally included in the study, an analysis is held on the examples cited from the source text, target text and the presented alternative text. In virtue of the mentioned analysis the domesticating elements in the translation are denoted through the given examples and this is scrutinized in terms of translation process and equivalence. The inferences obtained are discussed in detail under the given examples. In the evaluation part (also in the conclusion) domesticating elements in the target text are emphasized and then fields and/or terminologies which include the domesticating elements are clarified. Results and suggestions are included in the last part as well.

Keywords: Die Bürgschaft, Ali Bey Hüseyinzade Turan, Domestication Strategy, Translation Analysis, Ballad

\section{Giriş: Çalışmanın önemi, amacı ve kapsamı}

Bu çalışma, Friedrich von Schiller’in Almanca "Die Bürgschaft" adlı baladının Türkçeye Ali Bey Hüzeyinzâde (Turan) tarafından aktarılmış olan ve 1923 yllına tarihlendirilebilen "Kefalet Yahud Vefadar Dost(lar)" adlı çevirisini ele almaktadır. Yine aynı baladın günümüze daha yakın bir zamanda, günümüz Türkçesiyle, bir başka çevirisi olduğu da görülmüştür. ${ }^{3}$ Ancak araştırmalar neticesinde Schiller’in bu baladının ilk Türkçe çevirisinin Hüzeyinzâde Turan'a ait olduğu tespit edilmiştir. Hüseyinzâde Turan'ın çevirisinin yazı ve dilinin günümüze nazaran görece zor anlaşılır olması alternatif bir başka çeviri çabasına girilmesi ile sonuçlanmıştır. Çalışmanın önemi, orijinal eserin günümüz Türkçesiyle ikinci bir çevirisinin kazandırılmış olması ve ilk çevirisinin önce anlaşılır hale getirilip (transkripsiyon ve açıklama) sonra da çeviride yerlileştirme stratejisi açısından incelenmesidir. Çalışmanın amacı içerisinde, çevirinin incelenmesinde tercih edilen yerlileştirme stratejisinin nasıl uygulanmış olduğunun tespit edilmesi yer almaktadır. Bu amaca yönelik olarak orijinal eserin erek okur açısından yerlileştirici bir strateji ile çevrilmiş olduğu iddia edilmekte, incelemede buna yönelik örneklere yer verilmektedir. Mevcut çalışmanın kapsamı yine çalışmanın amacına uygun olarak çeviri metinden yerlileştirme unsurlarının tespiti, bu unsurların orijinal metin ile anlaşlırlığı artırmak adına önerilen alternatif çeviri metin (yeni bir çeviri) desteğiyle karşılıklı incelenmesi şeklindedir. Örneklerin incelendiği bölümde yer yer çeviri eşdeğerliğine4 ilişkin tespitlerde de bulunulmuştur. Çalışmanın

3 "Rehine” başlı̆̆ ile Türkçeye çeviren Burhanettin Batıman için bkz.; Schiller, Friedrich von. (1959). Balad’lar ve Şiirler, (Çev. Burhanettin Batıman), İstanbul Mat. Bkz. ayr.; Burçoğlu Kuran N. (2010). Çeviriye Bilimsel Yaklaşımlar. İstanbul: Multilingual (s. 80, 94-104).

$4 \quad$ Çeviri eşdeğerliğine yönelik çıkarımlarda adı geçen eşdeğerlik türleri, Werner Koller’in eşdeğerlik sınıflandırmasında açıkladığı manada kullanılmaktadır. Bunlar kısaca şu şekildedir: 1) Düz anlamsal Eşdeğerlik (denotative Äquivalenz): İçeriksel/içerik düzeyinde değişmezliktir. 2) Yan anlamsal Eşdeğerlik (konnotative Äquivalenz): Metin içerisinde söz söyleme biçiminin yan anlamlarla/çağrısıımlarla gerçeklestirilmesidir. Bu yan anlamlar sınıfsal yapı, topluluk (grup) dili, coğrafi boyutlar ve frekans (geliş-gidiş) vb. durumlara iliş̧kin olarak aktarımda yer alırlar. Metin içerisindeki söz söyleme biçimi, bilhassa eşanlamlı ya da eşanlama yakın ifade imkânları arasından yapılan özgün seçim aracılığıyla aktarılır. Koller bu kategoriye ait Eşdeğerlik kavramına yan anlamsal Eşdeğerlik der. 3) Metin kurallarma dayah Eşdeğerlik (textnormative Äquivalenz): Belirli bir metin türü için geçerli olan metin ve dil kurallarına (gelenek, görenek ve adetlerin dile yansımıs kaidelerine) dayanan Eşdeğerlik türüdür. Metin türüne özgün niteliklerle ilgilidir. 4) Edimsel Eşdeğerlik (pragmatische Äquivalenz): Çevirinin yönelmiş olduğu alıcı (okuyucu) ve bu alıcının anlama koşullarını temel alarak oluşturulmuş çeviri metinden bahsedilir. Özellikle, çevirinin alıcıya ayarlanabilmesi beklenir. Bu türden, alıcıyı muhatap alan ve iletissimsel işlevini tamamlayabilen metinler için söz konusu olan Essdeğerlik kavramıdır. 5) Biçimsel-estetikle ilgili Eşdeğerlik (formal-ästhetische Äquivalenz): Kaynak metnin biçimsel ve bireye ait (yazar ya da anlatıcı) biçemsel özellikleriyle ilgili Eşdeğerlik kavramıdır (Koller, 2011: 219). Detaylı bilgi için bkz. ayr.; Koller, W. (2011). Einführung in

Adres

Kırklareli Üniversitesi, Fen Edebiyat Fakültesi, Türk Dili ve Edebiyatı Bölümü, Kayalı Kampüsü-Kırklareli/TÜRKIYYE e-posta: editor@rumelide.com 
An exemplification of domestication: Translation of Friedrich von Schiller's ballad “Die Bürgschaft” into Turkish by Ali Bey Hüseyinzâde (Turan) / A. Uca; F. Soysal (pp. 784-815)

kapsamı gereği bu tür tespitlerden mümkün olduğunca kaçınılmasına rağmen eldeki çeviri metnin içerdiği unsurların aktarımı ile yerlileştirme stratejisi arasında bağlantı kurulabilen örneklerde lüzumlu görüldüğünden bu türden tespitlere kısmen başvurulmuştur.

\subsection{Kaynak ve çeviri metnin biçimi}

"Die Bürgschaft" baladis, her biri 7 dizeden meydana gelmiş toplam 20 kıtadan oluşmaktadır. Balatta pek çok stilistik unsur (Anaforlar, Tarizler, Enjambmentler: (Bir dizede anlam tamamlanmadığı zaman onu tamamlayacak kelimelerin ikinci diziye bırakılması 6 ), apostroflar vb.) kullanılmıştır.7 Mevcut çalışmada incelenen Ali Bey Hüseyinzâde'nin "Kefalet Yahud Vefadar Dost(lar)" başlıklı çevirisi ise her biri 8 dizeden oluşan yine toplam 20 kita olacak şekilde biçimlendirilmiştir.

die Übersetzungswissenschaft, (8. Auflage). Tübingen: A. Francke Verlag. (s. 219-268). Ayrıca "çeviribilimde eşdeğerlik" tanımlarına ve tartışmalarına, diğer eşdeğerlik sınıflandırmalarına yönelik detaylı bilgilere ulaşmak ve çalışmada sözü edilen "işlevsel eşdeğerlik" ve "üst düzey eşdeğerlik" ifadeleriyle ilgili genel manada bilgi edinmek için bkz.; Soysal, F. (2012). Eşdeğerlik ve Skopos Kuramını Çeviri Eylemine Uygulanabilirlikleri: Bertolt Brecht Çevirilerine Eleştirel Bir Yaklaşım. (Yayınlanmamış Yüksek Lisans Tezi). Selçuk Üniversitesi. (s. 7-41, 43-45, 84, 98-102, 111-112, 155). Bkz. ayr.; Soysal, F. “Werner Koller'in Eşdeğerlik Sınıflandırmasına Farklı Bir Yaklaşım”, içinde Proceedings Book of Uluslararası Dil ve İletişim Sempozyumu: Araştırma Eğilimleri ve Güçlükler. Erzurum: Mega Press. (s. 1429). "Eşdeğerlik” hususunun eldeki çalışmanın kapsamı dışında kalan bir konu olduğu burada yinelenerek sadece, bilhassa, "çeviribilimde eşdeğerlik kavramı"na ilişkin daha detaylı bilgi iceren, yerli ve yabancı ceviribilim literatüründe yer alan ileri okumalara yönelik başlıca bazı kaynaklar şöyle sıralanabilir: Akbulut, Ayşe Nihal. (2004). Söylenceden Gerçekliğe, İstanbul: Multilingual; Aksoy, N. Berrin. (2002). Geçmişten Günümüze Yazın Çevirisi. Ankara: İmge Kitapevi Yay.; Aktaş, Tahsin. (1995). "Çeviri İşlemi ve Eşdeğerlik”. G.Ü. Gazi Eğitim Dergisi, Yeni Dönem, S.3.; Aktaş, Tahsin. (1996). Çeviri İşlemine Genel Bir Bakış. Ankara: Orsen Mat.; Albrecht, Jörn. (1998). Literarische Übersetzung. Geschichte, Theorie, kulturelle Wirkung, Darmstadt; Eruz, Sakine. (2003). Çeviribilim: Çeviriden Çeviribilime. İstanbul: Multilingual; Yazıcı, Mine. (2010). Çeviribilimin Temel Kavram ve Kuramları, (2. Baskı). İstanbul: Multilingual; Alexieva, Bistra. (1993). A Cognitive Approach to Translation Equivalence. Translation as a Social Action. (yay. haz. ve çev. Palma Zleteva), Londra and New York: Routledge; Apel, Friedmar. (2003). Literarische Übersetzung. (2. Aufl.), Weimar: J. B. Metzler Verlag; Baker, Mona. (1992). In Other Words: A Coursebook on Translation. Routledge; Bassnett, Susan. (2002). Translation Studies, (Third Edition). London and New York: Routledge; Boztaş, İsmail. (1993). "Çeviri, Çevimen, Dilbilim İlişkisi, Çeviride Eşdeğerlik ve Kayıplar”. H.Ü. Edebiyat Fakültesi Dergisi. Cilt 10, Sayı 2, Ankara; Burçoğlu Kuran, Nedret. (2010). Çeviriye Bilimsel Yaklaşımlar. İstanbul: Multilingual; Catford, John C. (1965). A Linguistic Theory of Translation. Londra: Oxford University; Doğan, Gürkan. (1995). Çeviride Doğallkk ve Bağınt, Çeviribilim 1. (yay. haz. Işın BengüÖner), Bursa: A.Ü. Tömer Bursa Şubesi; Giuseppe, Palumbo. (2009). Key Terms in Translation Studies. Continuum International Publishing; Göktürk, Akşit. (1980). "Dilbilimsel Çeviri Kuramı". Türk Dili Aylık Dil ve Yazın Dergisi, Ankara: MEB.; Göktürk, Akşit. (2010). Çeviri: Dillerin Dili. İstanbul: YKY.; Halverson, Sandra L. (1997). The Concept of Equivalence in Translation Studies: Much Ado About Something. Target 9 (2); Jakobson, Roman. (1959). On Linguistic Aspect of Translation. On Translation, Cambridge: MA. Harvard University Press; Jäger, Gert. (1968). "Elemente einer Theorie und Technik des Übersetzens. Grundfragen der Übersetzungswissenschaft”. Beihefte zur Zeitschrift Fremdsprachen, 2., 35-52; Köksal, Dinçay. (2008). Çeviri Eğitimi-Kuram ve Uygulama. Ankara: Nobel; Koller, Werner. (2011). Einführung in die Übersetzungswissenschaft, (8. Auflage). Tübingen: A. Francke Verlag; Kurt, Rein. (1983). Einführung in die Kontrastive Linguistik. Darmstad; Munday, Jeremy. (2001). Introducing Translation Studies, Theories and Applications. London and NewYork: Routledge; Newmark, Peter. (1988). A Textbook of Translation. Hertfordshire: Prentice Hall International; Nida, Eugene A. (1964). "Toward a Science of Translation. with Special Reference to Principles and Procedures Involved in Bible Translating". Leiden; Pym, Anthony. (2010). Exploring Translation Theories. London and New York: Routledge; Pym, Anthony. (2012). "What happened to Equivalence?". http://usuaris.tinet.cat/apym/on-line/powerpoint.html, (Erişim Tarihi: 23.09.2019); Reiss, Katharina, Hans J. Vermeer. (1984). Grundlegung einer allgemeiner Translationstheorie. Tübingen: Max Niemeyer; Ricoeur, Paul. (2008). Çeviri Üzerine, (2006). (Çev. S. Ö. Kasar). İstanbul: Yapı Kredi Yay.; Rifat, Mehmet. (2003). "Göstergebilim Açısından Çeviri Etkinliği. Çeviri Kuramı ve Çeviri Kuramının Kuramı”. Çeviri Seçkisi 1. İstanbul: Dünya Yay.; Stolze, Radegundis. (2011). Übersetzungstheorien. (6. Aufl.), Tübingen: Narr Verlag; Suçin, Mehmet Hakkı. (2007). Öteki Dilde Var Olmak. İstanbul: Multilingual; Thome, Gisela. (2012). Übersetzen als Interlinguales und Interkulturelles Sprachhandeln. Berlin: Frank \& Timme; Toury, Gideon. (1980). In Search of a Theory of Translation. Tel Aviv: Tel Aviv University; Ülsever, R. Şeyda. (1999). Linguistic Aspects of Translation Evaluation. Eskişehir: Anadolu Ü. Yay. 1157; Wills, Wolfram. (1977). Übersetzungswissenschaft Probleme und Methoden. Stuttgart: Klett; Wills, Wolfram. (1982). The Science of Translation, Tübingen: Günter Narr Verlag.

51798 ylında Friedrich von Schiller tarafından kaleme alınarak yazımı tamamlanmış, 1799 ylında ilk kez onun Musenalmanach'ında (Sanat Almanakı/Yıllı̆̆ı) yayınlanmıştır. Krş. https://www.friedrich-schillerarchiv.de/inhaltsangaben/schiller-die-buergschaft-inhaltsangabe-interpretation-und-quelle/. (Erişim Tarihi: 10.12.2019).

$6 \quad$ Bkz. https://medium.com/@natamadergi/bir-tan\%C4\%B1t\%C4\%B1m-dil-\%C5\%9Fiiri-l-a-n-g-u-a-g-e-poetrya6c5bocb597c. (Erişim Tarihi: 15.12.2019).

Bkz. https://www.mein-lernen.at/component/content/article?id=3171:ballade-die-buergschaft-friedrich-schiller. (Erişim Tarihi: 12.12.2019). 


\subsection{Kaynak metnin konusu}

Friedrich von Schiller'in "Die Bürgschaft” adlı baladının konusu ile ilgili ulaşlan kaynaklarda hemen hemen aynı tarihli anlatıya işaret edildiği görülmektedir. Balat, Möros ve Selinuntius arasındaki gerçek bir dostluk hakkındadır. Möros, Tiran (kral) Dionysius'u bir hançerle öldürmek ister, ancak bu eylemini gerçekleştiremez ve kralın yakın korumaları tarafından yakalanır. Ölümle karşı karşıya kalan Möros, Dionysius'tan kız kardeşinin evlenebilmesi için üç gün mühlet vermesini ister. Dönüşü için bir teminat olarak, arkadaşı Selinuntius'u krala sunar. Kral, eğer Möros zamanında geri dönmezse kendisinin özgür (suçsuz) sayılacağını ve arkadaşı Selinuntius'un onun yerine infaz edileceğini bildirir. Dönüş yolunda Möros, köprüleri yıkacak kadar nehrin kabarmasına neden olan şiddetli yağmurlar tarafından engellenir. Bu yüzden Möros ümitsizliğe kapılır. Çünkü arkadaşını mutlaka kurtarmak ister. Bütün cesaretiyle şiddetle kabaran sulara dalar ve bir şekilde kıyıya ulaşmayı başarır. Sonrasında soyguncular peyda olur ve onun üzerine saldırır. $O$ ise bütün kuvvetiyle onlarla dövüşür, hatta içlerinden üçünü öldürür. Bir başka imtihan olarak bu sefer de susuzluktan ölmekle burun buruna gelir. Ancak arkadaşını kurtarma arzusundan vazgeçmez. Yer altından çıkan bir pınar Möros'u kurtarır. Tüm bunlar yaşanırken ona tanınan mühlet de azalmaktadır. O sıralarda arkadaşı Selinuntius çoktan çarmıha gerilmiştir. Fakat o, arkadaşı Möros'un döneceği ümidini yitirmez. İnfaz yerinde Möros, son anda kendisini gösterir. Kral Dionysius, bu gerçek sadakat ve dostluk karşısında duygulanır, etkilenir ve bu yüzden beklenmedik bir biçimde her ikisinin de canını bağışlar. ${ }^{8}$ Görüldüğü üzere tarihi anlatıdaki Möros, balatta Damon adıyla yer almaktadır. Tiran, yani Kral Dionysius ise Dionysos olarak kısmen adını korumaktadır.

\subsection{Erek metin ve çevirmen}

"Die Bürgschaft" baladını kaynak metnin biçimine bağlı kalarak Türkçeye "Kefalet Yahud Vefadâr Dost(lar)" başlı̆̆ıyla aktaran çevirmen Ali Bey Hüseyinzâde (Turan)'dır. Ali Bey Hüseyinzâde, Turan soyadını sonradan almıştır. Çevirinin gerçekleştirildiği zaman kesin olarak bilinmese de çeviri 1923 yılında iki yerde yayınlanmıştır. Bunlardan biri İçtihad dergisidir. (İçtihad 1923: 159; 3265-3266). Biri de bağımsız kitapçıktır. (Hüseyinzade Ali 1923: 1-24). İçtihad dergisinde ve bağımsız kitapçıkta yayınlanan çeviri metinleri incelendiğinde her iki metnin birbirinin aynısı olduğu görülse de 84 . dizede küçük bir farklılık göze çarpmaktadır. Zira İçtihad' da "Hakkı o da şimdi bir müstebidin!" dizesi kitapçıkta "O da hakkı şimdi bir müstebidin!” şeklinde ifade edilmiştir. (Hüseyinzade Ali 1923: 15). Çevirinin yayınlandığı 1923 yılında Anadolu'da Arap alfabesi kullanılmakta olup Cumhuriyet yeni ilan edilmiştir. Dolayısıyla erek metnin çevirmeni Hüseyinzâde Ali adıyla anılmaktadır. Soyadı kanunu henüz çıkmamıştır. 9 Basıldığı yıl ise Cumhuriyet’in ilan edildiği yıla denk gelmektedir. Bu durumda erek metin 1923 yllna tarihlendirilebilir.

Ali Bey Hüseyinzâde Turan, 24 Şubat 1864 tarihinde Bakü'nün Salyan kasabasında doğmuştur. Tiflis’te lise öğrenimini tamamladığı sırada Rusça, Latince, Fransızca ve Almanca öğrenmiş, dünya edebiyatını tanımaya çalışmış, özellikle Goethe'yi çok sevmiştir. Edebiyatın yanı sıra tarihe de ilgi duymuştur. 1885 ylında girdiği Petersburg Üniversitesi Fizik-Matematik Fakültesini 1889'da bitirmiştir (Paşayeva ve Turan 2014: 11). Bu okulda öğrenci iken Mendelyef, Menşutkin, Vagner ve Beketof gibi devrin ünlü hocalarını tanımak fırsatı bulmuştur. Aynı zamanda Homer, Dante, Tasso, Schiller, Byron gibi Batı klasiklerini anlamaya çalışmıştır. 1890 yılında İstanbul'da Askeri Tıbbiyeye öğrenci olarak girmiştir. Burada sonradan şöhret olan Abdullah Cevdet, Şerafettin Mağmumi, İbrahim Temo, Cenap Şahabettin,

$8 \quad$ Bkz. https://www.mein-lernen.at/component/content/article?id=3171:ballade-die-buergschaft-friedrich-schiller. (Erişim Tarihi: 12.12.2019).

Çalışmanın bundan sonraki kısımlarında söz konusu erek metnin çevirmeni için "Hüzeyinzâde Turan" nitelendirmesi kullanılmaktadır. 
An exemplification of domestication: Translation of Friedrich von Schiller's ballad “Die Bürgschaft” into Turkish by Ali Bey Hüseyinzâde (Turan) / A. Uca; F. Soysal (pp. 784-815)

Rıza Tevfik, Bahattin Şakir, Dr. Nazım, İbrahim Tali, İshak Sükuti, Abdülkerim Sebati gibi pek çok ünlü isimle tanışmıştır. 1895 yılında bu okuldan Tabip Yüzbaşı olarak mezun olmuştur (Bayat 1998: 10,11). Doktorluk mesleğinin yanında siyasetle de uğraşmıştır. Ayrıca yazarlık, şairlik, ressamlık gibi yetenekleri olduğu anlaşılmaktadır. Batı dillerinden çeviriler yapmıştır. Çevirilerinden biri de balat olarak nitelendirilen, Schiller’in "Die Bürgschaft” adlı eseridir.

Hüseyinzâde Turan'ın Schiller'den yapmış olduğu söz konusu çeviriyle ilgili dile getirilen bir bilgilendirmede, onun "Die Bürgschaft" baladını Türkçeye aktarmayı tercih etmesinin tesadüf olmadığından söz edilmektedir. Buna göre, kaynak metinde işlenen Schiller’in müstebit bir yönetime karşı takındığı tutum; doğruluğun, dürüstlüğün, güvenin, vefanın, insanlığın öneminin vurgulanması gibi konular Hüseyinzâde Turan'ın bilhassa değer verdiği konulardandır. Dolayısıyla çevirmen sıfatılla Hüseyinzâde Turan'ın, kendisinin bizzat içinde yaşadığı toplumda var olan söz konusu değerlerin daha da pekişmesini sağlamak amacıyla mevcut çeviriyi gerçekleştirdiği dile getirilmektedir (Uca 2017: 224).

Hüseyinzâde Turan'ın Schiller'den çevirdiği balat hususunda seçici davranması ve erek kültür değerlerini pekiştirme amacı gütmesi çevirmenin, çeviri eylemine başlamadan önce dahi yerlileştirici stratejiyi -bilinçli veya bilinçsizce- hedeflemiş olduğu iddia edilebilir. Elbette o zamanlar yerlileştirme yöntemleri mevcut çalışmada açıklandığı kadar belirgin olmayabilir. Ancak strateji olarak gerçekleştirilmek istenen şey çeviride yerlileştirmedir.

Çevirmenin yerlileştirici stratejiyi önceden hedeflemiş olabileceği iddiasını güçlendirmek adına, Hüzeyinzâde Turan'ın, Turan soyadını nasıl ve niçin aldığı hususuna ayrıca değinmek gerekir. Hüseyinzâde Turan için en uygun soyadının "Turan” olabileceği, çünkü onun Turancıllk fikrinin ilk taraftarlarından biri olduğu dile getirilmektedir. Kendisinin kaleme aldığı "Turan" adlı bir şiirden de bahsedilmektedir. Hatta Turan sözcügünün siyasi manada Türk kavimleri birliğinin en son hedefi olması gerektiği Türkiye'de ilk defa Hüseyinzâde Turan tarafından ifade edilmiştir. Tüm bu sebeplerden ötürü onun "Turan”"10 soyadını alması tesadüf değildir (krş. Uca 2017: 188-189). Hüseyinzâde Turan'ın Turancılık anlayışı, onun dile, edebiyata ve çeviriye bakış açısını da şekillendirmiş gibidir. O, dilde sadeliği ve anlaşlırlığı savunur. Hem Batı dilinden ödünçleme yöntemiyle Türkçeye alınan sözcüklerin yerleşmesine hem de Eski Türkçenin sözcüklerinin ısrarla kullanılmasına karşı çıkmaktadır. Toplumun öz dilini öğrenmesi için çaba sarf etmekte, dil hususuna ayrıca önem vermektedir. Türk dilinin kapsayıcı ve yaygın bir dil olduğu kanaatindedir (krş. Uca 2017: 292). Dil konusunda çokça makale yayınlamış olan Hüseyinzâde Turan, Arapça için din ve mezhep dili, Farsça için şiir ve edebiyat dili nitelendirmelerinde bulunurken Türkçeyi yeni devir için ilerleme ve medeniyet dili olarak görmektedir. İdealleri arasında ise Türk dilini bir dünya dili olarak görebilmek yer alır (krş. Uca 2017: 294). Tüm bu idealleri ile soyadı yan yana getirildiği zaman, ona "Turan" soyadının verilmesinin isabetli olduğu kanaatine varılmaktadır.

\section{Balat üzerine birkaç söz}

Dans şarkısı anlamı ile İtalyanca çıkışlı (daha ziyade bölgesel / yöresel) olarak kaynaklarda yer alan Balat $^{11}$ 14. ve 15. yüzyllar arasında Fransız literatüründe Ballade olarak şiir / nazım formunda işlenmiş,

10 "Turan" soyadını nasıl aldığı ile ilgili detaylı bilgi edinmek için bkz. ayr. Türk Ansiklopedisi, M.E.B. Ankara, 1983, C.XXXII, s.3; Laszlo RASONYI, Tarihte Türklük, Ankara, 1971, s. 259; Dr. Alaattin UCA, İttihat ve Terakki Cemiyeti Kurucularından Türkçülük Fikrinin Ünlü Mütefekkiri, Ali Bey Hüzeyinzâde (TURAN), Hayatı Fikirleri ve Eserleri, Konya, Kömen Yayınları, 2017.

${ }_{11} \quad$ Balad olarak da kaynaklarda yer aldığı gözlemlense de TDK güncel sözlüğünde ve yazım kuralında Balat şeklinde yer aldığı için mevcut çalışmada Balat ifadesinin kullanımı tercih edilmiştir. Bkz. http://sozluk.gov.tr/. (Erişim Tarihi: 15.07.2019) 
nakaratlarla kullanılmıştır. 18. yüzyılda İngiliz literatürüne Ballad ifadesiyle halka dair ve epik şarkılar biçimde alımlanarak devşirilmiş, oradan ise Almanca literatüre geçmiştir. Almanca literatürde halk balatları olarak nazımlar oluşturulmuş, sonrasında 1777 yılından itibaren, sanat balatları yazılmaya başlanmıştır. Balatlarıyla ünlü Alman şairler sanat balatlarını iyi nitelikte icra ederek bu nazım türünü üne kavuşturmuştur (Bürger, Schiller, Goethe, Uhland, Meyer ve birçokları burada örnek olarak verilebilir) (krş. Best 1987: 52; krş. Wilpert 1979: 66-67). Halk öykülerinden türeyen şarkılar biçiminde ortaya çlkmış baladın Batı Edebiyatı'ndaki konumu bu şekilde tasvir edilmektedir.

Baladın Türk Edebiyatı'nda alımlanışı genellikle üç uzun bir de kısa bentten ${ }^{12}$ oluşan nazım biçimi şeklinde olmuştur. Uzun bentler altı ile on dize arasında değişmekle beraber kısa bentlerin dört ile beş dize arasında sınırlı olduğu belirtilmektedir. Sadece şiir olarak görülmeyen şarkı biçiminde de ortaya çıkabilen balatlar olduğundan o tür balatların nakarat bendi diye de adlandırılan bendinde tekrarlanan bir son dize yer almaktadır. Ayrıca kesin bir biçimde uyulması gereken bir kafiye düzeninden söz edilmemekte; içerdikleri konuların ise genelde masal ve efsane nitelikleri taşıdıkları belirtilmektedir. ${ }^{13}$ Yine farklı kaynaklarda baladın Batı kökenli bir nazım türü olduğu ve çoğunlukla efsanevi, masalımsı, bazen gülünç olayları konu edinen; bazen de söylentilerle eski hikayeleri işleyen üç uzun bir kısa bentten oluşan nazım veya şiir türü olarak tanımlandığı da görülebilmektedir. Batıdaki (etimolojik) manasına tarihsel açıdan bakıldığında Orta Çağ'da danslara eşlik eden ve hikâye biçiminde anlatılan lirik şiirlere balat denildiği görülmektedir. 18. yüzyıldan bugüne değin baladın geleneksel biçimini aldığı ve kısa anlatı şiiri şeklinde tanımlandığı dile getirilmektedir. Türk Edebiyatı’nda ise İkinci Meşrutiyet ve Cumhuriyet Dönemi’nde balat şeklinde şiir yazımına rastlandığı belirtilmektedir. Ancak -yukarıda açıklandı ̆̆ı üzere, baladın belli bir kafiye düzeni olmaması, bir bakıma şairin üslup ve tutumuna göre kafiyenin belirlenmesi söz konusuyken- Türk Edebiyatı'nda balatlarda genellikle çapraz kafiye düzeninin kullanılmış olduğuna dikkat çekilmektedir. ${ }^{14}$

Baladın tanımlaması yapılırken nazım türü olan balat için ayrı bir tanım getirildiği görülmektedir. Buna göre nazım türü olan balat, "genellikle bir öyküsü olan kısa lirik şïrlere veya duygusal şarkzlara, efsane ve aşk konularının işlendiği manzumelere verilen genel addrr”. Ayrıca Batı etkisiyle Türk şiirine geçen bu nazım şeklinin şairler tarafından fazla rağbet görmediği de dile getirilen hususlardandır. (Karataş 2018: 51).

Görüldüğü üzere, balat denince ilk dikkat çeken şey onun bir şiir / nazım biçimi olduğudur. Ancak çok bentli nazım biçiminde bir anlatı söz konusudur. Aynı zamanda onlar, dize ve bent kullanılarak kafiyelendirilen fakat belirli bir vezin ölçüsü bulunmayan metinler olarak tasvir edilir. Baladın tipik özelliği; şiirin, epiğin ve dramanın niteliklerini birleştirmesi ve bu üç ana türün bir melezini temsil etmesidir. Bilhassa, halk ve sanat balatları arasında farklılıklar oluştuğu kaynaklarda geçen ifadelerde yer almaktadır. Bu farklılıklar şu şekilde vurgulanabilir: Halk balatları sözlü geleneğe ve şarkıya olan yakınlıkları ile nitelendirilirken, sanat balatları yazılı olarak kaydedilmiştir. Bir yazar aracılığıyla ön plana çıkarılmıştır. Eğer balat söz konusuysa, genellikle 18. 19. ve 20. yüzyılın sanat balatlarının kastediliyor olduğu bilinmelidir. Kastedilen bu balatlar ise Bürger, Heine, Fontane, Goethe, Schiller vd. tarafından meydana getirilmiş olan sanat balatlarıdır, denebilir. ${ }^{15} \mathrm{Bu}$ çalışmada yer alan balat Schiller'e ait bir sanat baladıdır. Arka planında yer alan olaylar ise kahramanlık içeren bir halk hikayesine

\footnotetext{
12 Bent, bir şiirin 4, 5, 6, ve daha fazla dizeli / mısralı bölümlerinden her biri için kullanılan bir terimdir. (Y.N.). Bkz. ayr. “(...) bir şïri meydana getiren ikilik (beyit), üçlük, dörtlük, beşlik vd. kümelere de bend denmiştir.” (Karataş 2018: 54). Bkz. http://edebiyatsultani.com/bati-edebiyatindan-alinan-nazim-sekilleri/. (Erişim Tarihi: 20.07.2019). Bkz. https://www.turkedebiyati.org/balat.html. (Erişim Tarihi: 20.07.2019). Bkz. https://wortwuchs.net/ballade/. (Erişim Tarihi: 19.07.2019).
} 
dayanmaktadır. Dolayısıyla Schiller’in, halk ve sanat baladında karışık veyahut melez bir icraatta bulunmuş olduğu iddia edilebilir.

\section{3. Çeviride yerlileştirme tasvirleri}

Çeviri stratejilerinden çeviride yerlileştirme üzerine dile getirilen düşünceler, genel itibariyle yerlileştirmenin ne olduğunu değil nasıl yapılmakta olduğunu ortaya koymaktadır. Bu tespite dayanarak başlıkta tanım yerine tasvir sözcüğünün kullanımı daha uygun görülmüştür. Çeviride yerlileştirmenin nasıl tasvir edildiğine ilişkin kaynaklar daha ziyade bu konuyu çeviribilim açısından ele alan bilim insanlarından ve konuyla ilgili görüş bildiren düşünürlerden derlenerek aktarılmıştır.

Genel manasıyla çeviride yerlileştirme, erek dil okuyucuları için yabancı metnin tuhaflığını en minimal düzeyde yansıtmak uğruna şeffaf ve akıcı bir üslubun benimsendiği çeviri türünü belirtmektedir (Yang 2010: 77). Burada kullanılan tuhaflık ifadesi kaynak metindeki ilgili dilsel veya kültürel unsurlara işaret etmektedir. Dolayısıyla söz konusu tuhaf unsurların bilindik dil unsurlarına dönüştürülmesiyle bir yerlileştirme faaliyeti kastedilmektedir. Bir başka deyişle bu tasvire göre yerlileştirme, çevirisi gerçekleştirilecek kaynak metin unsurlarının erek dilde ve kültürde yer alan unsurlarla, alışlagelmiş bir imaj verilmesi amacıyla yer değiştirilmesi, çeviride tuhaflı̆̆ın ortadan kaldırılması süreci olarak tarif edilebilir.

Çevirinin amaçları arasında -yerlileştirmenin lehine olan- kültürel bir ötekinin aynılaştırılması, fark edilebilir hale getirilmesi ve alışılmış olanın yansıtılabilmesi gibi faaliyetler yer almaktadır. Çeviride bu türden faaliyetlerin amaçlanması, her zaman yabancı metnin bütünüyle yerlileştirilmeye maruz kalmasına neden olabilmektedir (krş. Venuti 1995: 18; krş. ayr. Taş 2017: 7). Burada yerlileştirmenin kulağa olumsuz gelen bir yanı da varmış gibi bir izlenim hasıl olmaktadır. Çevirmenin yerlileştirme stratejisini benimsemesinin çeşitli nedenlerinden söz edilebilir. Bir örnek vermek gerekirse, çevirmen yaşadığı dönemin siyasi ve kültürel gerçekliklerine göre yerlileştirmeyi tercih edebilir (krş. Venuti 1998: 240-241; krş. ayr. Taş 2017: 7). Örnekleri çoğaltmak adına çevirmenin erek kültürdeki çeviri geleneğini sürdürme isteği, aykırı olmaktan çekinmesi ya da bilinçsizce çeviride yerlileştirme stratejisini benimsemiş olması gibi nedenler de sıralanabilir. Yerlileştirme stratejisi gereğince bir çevirmen, çeviri sürecinde tuhaf görünen kültürel unsurları erek dile aktarırken onları tamamen çıkarma, atlayarak çevirme, değiştirme, onlara ekleme yapma, onları erek (özgün) kültüre uyarlama, işlevsel çeviri kuramlarına uygun hareket etme gibi çeviri uygulamalarına başvurabilmektedir. (krş. Taş 2017: 7). Çevirmenin belirlediği herhangi bir stratejinin tüm çeviri ürünü etkileyeceği kaçınılmazdır. Yerlileştirme stratejisinin ne türden etkiler doğurabileceğine burada böylece yer verilmektedir.

Yerlileştirici çeviri, yabancı metnin dilsel ve kültürel farkının, erek dil okuyucusuna anlaşılabilir gelen bir metinle yer değiştirilmesi olarak da ifade edilebilir (Venuti'den aktaran Birdwood Hedger 2006: 262). Burada yine dilsel ve kültürel ögelerin tuhaflıklarından arındırılması faaliyeti farklı bir biçimde tasvir edilmektedir.

Bir başka açıdan bakıldığında, çeviriler kaçınılmaz olarak yerlileştirmenin icraata dökülmesi şeklinde yorumlanabilmektedir. Bunu en iyi sergileyen çeviriler kültürel değerlerin yeniden inşasında en çok etkili olan ve söz konusu etkiyi dikkate almada en fazla sorumluluk duyan, genellikle bir dereceye kadar yerli ifadelerle okumaya alışkın okuru kendilerine çekerler. Böyle çeviriler bu türden okurları yabancı 
bir metindeki yeniden yorumlamalarla (revizelerle) büyülerler ${ }^{16}$. (Venuti 1998: 5). Yerli ifadelerin erek metinde yer bulması erek metin okuru açısından sürekli yeni yaklaşımlar / fikirler, yeni ufuklar ve yorumlar içererek onlara cezbedici gelmektedir. Yerlileştirmenin okumayı alışkanlık haline getirmiş okurun ilgisini çekme hususunda başarılı bir kültürel çeviri aracı olduğu söylenebilir.

Çeviri eylemi daima bir yerlileştirme sürecini içermektedir. Bu süreç, kaynak dilin anlaşlabilir olanlarının erek dildekilerle yer değiştirmesidir. Ancak yerlileştirme asimilasyon şeklinde algılanmamalıdır. Çünkü yerlileştirme, yabancı metnin baskın yerli değerlere tutucu bir indirgemesi değildir. ${ }^{17}$ (Venuti 2004: 203). Yabancı metnin kültürel unsurlarının erek kültürde erimesi ve erek metinde tamamı ile yerlileştirilmesi, istenen ve umulan bir çeviri faaliyeti olarak görülmemektedir. Bunu destekler nitelikteki bir görüşe göre; önceden var olan kültürel ögeler, çeviri için kültürel özerklik iddiasıyla "hayaletlere" dönüşerek yavaş yavaş yok olmaktadır. Bu ise çeviri için erek dilin değerleriyle yabancı metni yazan, gerek dilsel (akıcılı̆̆ı sağlayan) gerekse de kültürel nitelikte (bir Yahudi- Hristiyan tek tanrıcılı̆̆ına uygun olarak "Zeus” için “Tanrı” karşılığı gibi) kapsamlı bir yerlileştirmeyi uygulanabilir hale getirmektedir. ${ }^{18}$ (Venuti 2004: 210). Bu noktaya yöneltilen eleştiri kültürel değerlerin özgünlüğünü yitirmesi pahasına yerlileştirilip yerlileştirilmemesi ile ilgilidir. Bu sebepten belki de "çeviride etik" tartışması içerisinde değerlendirilmesi gerekir.

Bir diğer görüşte yerlileştirme ile alakalı bir riske dikkat çekilmektedir. Bu, özgün yazarların tarzlarının ve hitap biçimlerinin ait olduğu uluslara özgü dil kandırmacalarının yalın ve yavan bir tekdüzeliğe indirgenmesi riskidir. Fakat Cohen "en iyi" çevirilerin bu "tehlikeden" kaçınabildiğine inanmaktadır. ${ }^{19}$ (Cohen'den aktaran Venuti 2004: 6). Bu risk, kaynak metnin yazarının üslubunun kaybolma riski olarak kısaca özetlenebilir. Cohen'in dile getirdiği söz konusu tehlikeden kaçınılması, nihayetinde çevirmen ile ilişkilendirilmektedir.

Yerlileştirmenin bir bakıma yabancı metnin yabancılaştırıcı etkilerinden bazılarıyla mücadele etmek için şeffaf ve akıcı bir tarz geliştirmeye meyleden çeviri yaklaşımı olduğundan bahsedilmektedir. Yerlileştirmenin tersi bir strateji olarak yabancılaştırma ise kaynak metnin yabancıllğını bir miktar muhafaza ederek kasten erek dilsel ve kültürel gelenekleri bozan bir çeviri stratejisi şeklinde tasvir edilmektedir $^{20}$ (krş. Hatim 2014: 51). Dolayısıyla bir çevirmenin yabancılaştırma stratejisini uygulaması, yerlileştirici unsurlara erek metinde yer vermemesi anlamına gelebilecektir.

Yerlileştirme ve yabancılaştırma stratejileri arasındaki ayrımı vurgulayarak açık bir biçimde belirtme gereği duyan Friedrich Schleiermacher, 1813'te "Çevirinin Farklı Yöntemleri Üzerine" başlıklı makalesinde, iki stratejinin varlığından söz eder ve onları tartışmaya açar. Schleiermacher’in vardığı

16 Bkz. orijinal alıntı: "Translations, in other words, inevitably perform a work of domestication. Those that work best, the most powerful in recreating cultural values and the most responsible in accounting for that power, usually engage readers in domestic terms that have been defamiliarized to some extent, made fascinating by a revisionary encounter with a foreign text." (Venuti 1998:5).

17 Bkz. orijinal alınt: "Translation, then, always involves a process of domestication, an exchange of source-language intelligibilities for target-language ones. But domestication need not mean assimilation, i.e., a conservative reduction of the foreign text to dominant domestic values." (Venuti 2004: 203).

18 Bkz. orijinal alıntı: "Preexisting cultural materials fade into "ghosts" with the claim of cultural autonomy for the translation, which can then carry out a thoroughgoing domestication that inscribes the foreign text with target-language values, both linguistic (fluency) and cultural (a Judeo-Christian monotheism-“writing 'God' for 'Zeus'”).” (Venuti 2004: 210).

$19 \quad$ Bkz. orijinal alıntı: "Cohen also noticed the domestication involved here, "the risk of reducing individual authors' styles and national tricks of speech to a plain prose uniformity," but he felt that this "danger" was avoided by the "best" translations." (Venuti 2004: 6).

2o Bkz. orijinal alintı: "Domestication (...) is seen as an approach to translation which, in order to combat some of the 'alienating' effects of the foreign text, tends to promote a transparent, fluent translating style. This is contrasted with foreignisation, a translation strategy which deliberately breaks target linguistic and cultural conventions by retaining some of the 'foreignness' of the source text”. (Hatim 2014: 51). 
An exemplification of domestication: Translation of Friedrich von Schiller's ballad “Die Bürgschaft” into Turkish by Ali Bey Hüseyinzâde (Turan) / A. Uca; F. Soysal (pp. 784-815)

neticeye göre çevirmen, ya yazarı olabildiğince rahat bırakır ve okuyucuyu yazara doğru yönlendirir ya da okuyucuyu olabildiğince rahat bırakır ve yazarı okuyucuya yönlendiririr ${ }^{21}$ (krş. Schleiermacher 1813/1963: 47). Her iki stratejinin çevirmen, yazar ve okuyucu üçgeninde adeta bir somutlaştırılma çabası burada dikkat çekmektedir.

17. ve 18. yüzylların çeviri kuramı ve uygulamasında yerlileştirme basmakalıp bir ifade olarak kullanılmaktadır. Aynı zamanda, çevirmenler bir kayıp ve kazanç oranının kaçınılmaz olarak çeviri sürecinde gerçekleştiğini kabul eder ve çeviriyi yabancı metne eş sesli bir ilişki içerisinde konumlandırır. Onlar, en azından teoride, kaynak metnin yazarının özgün tarzına saygı duymaktadır. Örneğin, Dryden, bir çevirmenin "onu diğer herkesten ayıran bir yazarm karakterini" koruması gerektiğine dikkat çekmektedir. ${ }^{22}$ (Steiner'den aktaran Birdwood Hedger 2006: 22). Günümüzden yaklaşık üç yüz yll öncesinde yerlileştirmenin stratejik boyutuyla algılanmadı̆̆ı ve bugünkü manasıyla ciddi bir biçimde irdelenmediği kanaati bir kez daha burada dile getirilmiş olmaktadır. Ayrıca çeviri uygulamalarına kuramsal düşüncenin tamamen yansımamış olmasına rağmen özgün yazarların üslubunun korunması gerektiği fikrinin hâkim olduğu anlaşlmaktadır.

1937'de konuyla ilgili kaleme alınmış bir makalede, yabancılaştırma ve yerlileştirme meseleleri ele alınmaktadır. Burada, farklı diller ve dünya görüşleri arasında indirgenemez başkalıklar içerisindeki çevirinin sefaletine işaret edilir. Neticede, çevirinin ihtişamının okuyucuyu dil alışkanlıklarından siyrılmaya zorlayabilme ve onu yazarınkilerle birlikte hareket etmeye mecbur birakabilme kudretiyle olanaklı olabileceği kanaatine varılır'3 (Gasset'ten aktaran Birdwood Hedger 2006: 40). Yerlileştirmenin tam tersi niteliğinde sunulan yabancılaştırma stratejisinin çeviriye ihtişam katacağı savunulmaktadır. Oysaki hangi strateji ile daha kaliteli çeviri ürünler elde edilebileceği hususu hâlihazırda tartışmalıdır.

Çeviribilime yayarak yerlileştirme betimlenmek istense, erek dilin ve kültürün kaynak dile ve kültüre üstünlüğ̈̈ ve kaynak metnin alıcı kültür tarafından kullanılan bir nesne olarak hizmet ettiği sonucuna varılır. ${ }^{24}$ (krş. Tian 2010: 79). Ayrıca yerlileştirmenin etimolojik manası, insanın gerçekleştirdiği çeviri etkinliğindeki düşünceyle bağdaşmaktadır. Bu görüş; erek dilin ve kültürün, kaynak dile ve kültüre üstün geldiği görüşüdür. ${ }^{25}$ (krş. Tian 2010: 93). Buradan da anlaşllabileceği üzere, yerlileştirme stratejisi kaynak kültür ve erek kültür arasında üstünlük sağlama meselesi gibi görülerek de ele alınabilmektedir.

Düz yazı çevirileri ve yerlileştirme stratejisi arasındaki ilişkiden bahsederken şiir çevirisinin de çeviribilimin meseleleri arasında yer aldığını unutmamak ve çeviri stratejileri açısından nasıl ele alındığına kısaca yer vermek gerekir. Şiir çevirisi üzerine yapılan bir değerlendirmede, yabancılaştırma ve yerlileştirme stratejileri arasındaki seçimin şiir çevirmenlerini nesir çevirmenlerinden daha fazla

${ }_{21} \quad$ Bkz. orijinal alıntı: "Meines Erachtens gibt es deren nur zwei. Entweder der Übersetzer lässt den Schriftsteller möglichst in Ruhe, und bewegt den Leser ihm entgegen; oder er lässt den Leser möglichst in Ruhe und bewegt den Schriftsteller ihm entgegen." Erisim Adresi: http://users.unimi.it/dililefi/costazza/programmi/2006-07/Schleiermacher.pdf (20.07.2019).

${ }_{22} \quad$ Bkz. orijinal alıntı: "Thus domestication was a commonplace in the 17th-18th centuries' translation theory and practice. At the same time, translators recognised that a ratio of loss and gain inevitably occurs in the translation process and situates the translation in an equivocal relationship to the foreign text. They respected, at least in theory, the original author's individual style. Dryden, for instance, declared that a translator must maintain "the character of an author, which distinguishes him from all others"

$23 \quad$ Bkz. orijinal alıntı: "The Spanish philosopher Jose Ortega Y Gasset discussed the issues of foreignization and domestication in his 1937 essay. He saw the misery of translation in the irreducible differences between different languages and world visions. The splendour of translation is the ability to 'force the reader from his linguistic habits and oblige him to move with those of the author"

24 Bkz. orijinal alıntı: "Extended to Translation Studies, domestication implies that the target language and culture is superior to the source language and culture, and that the source text serves as an object used by the receiving culture."

Bkz. orijinal alıntı: "The etymological sense of domestication agrees with the notion in human translation practice that the target language and culture is superior to the source language and culture."

Adres

Kırklareli Üniversitesi, Fen Edebiyat Fakültesi, Türk Dili ve Edebiyatı Bölümü, Kayalı Kampüsü-Kırklareli/TÜRKIYE e-posta: editor@rumelide.com
Address

Kurklareli University, Faculty of Arts and Sciences, Department of Turkish Language and Literature, Kayalı Campus-Kırklareli/TURKEY e-mail: editor@rumelide.com 
etkilediği iddia edilmektedir. Şayet şiir, hâlihazırda küçük bir azınlık tarafından okunuyorsa o halde yabancı izlenimi veren versiyonları yayınlamanın ticari risklerinin de daha az önem arz ettiği vurgulanmaktadır26 (krş. Birdwood Hedger 2006: 46). Çeviri eserlerin ticari boyutuna ilişkin çeviri şiirlerin basılıp basılmamasında çevirmenin hangi stratejiden yararlanmış olduğunun çok fazla etkili olmadığı burada iddia edilmektedir. Bir diğer ifadeyle, şiir çevirileri için kullanılan strateji satış rakamlarını etkilememektedir. Çünkü bu iddiaya göre, şiir okuru bellidir ve bir bakıma sabittir. Okur sayısının çok fazla değişmeyeceği öngörülmektedir.

Yabancılaştırmayı ve yerlileştirmeyi mevcut düzlemde analiz etmek için çevirmenin inançlarına ve ayrıca çevirmenin, yazarın inançlarına karşı tutumuna aşina olmak gerekir. Yazarın ve çevirmenin aynı tarihsel dilimde yaşadıkları zaman ortak bir duyarlılığı paylaşma olasılıklarının daha yüksek olduğu ve çevrilen metnin aslına uygunluğunun arttı̆̆ ileri sürülmektedir. Dolayısıyla okuyucunun sempati (simpatico) prensibine göre yapılan herhangi bir çeviride duyduğu ses, daima yazarın sesi olarak bilinecektir; asla bir çevirmeninki olarak değil ya da ikisi arasındaki melez bir ses olarak hiç değil (aktaran Birdwood Hedger 2006: 257; bkz. ayr. Venuti 2004: 273). Buradaki iddiaya göre yazar ve çevirmenin tarihsel olarak ve arka plan (habitus da denebilir) bakımından bütünsellik sağlaması, söz konusu bir çeviri üründe çevirmeni her halükârda görünmez kllacaktır. Bu minval üzere, yabancılaştırma ve yerlileştirme stratejilerinin farklı bir zeminde değerlendirilmesi uygun olacaktır.

\section{Kaynak (orijinal) metin, erek (çeviri) metin ve sunulan alternatif çeviri metin}

\begin{tabular}{|c|c|}
\hline $\begin{array}{l}\text { 4. 1. Kaynak metin: "Die Bürgschaft" (Yazar ve } \\
\text { Şair: Friedrich von Schiller, 1798) }\end{array}$ & 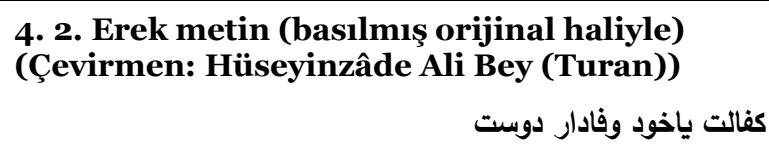 \\
\hline $\begin{array}{l}1 \\
\text { Zu Dionys, dem Tyrannen, schlich } \\
\text { Damon, den Dolch im Gewande: } \\
\text { Ihn schlungen die Häscher in Bande, } \\
\text { "Was wolltest du mit dem Dolche? Sprich!” } \\
\text { Entgegnet ihm finster der Wüterich. } \\
\text { "Die Stadt vom Tyrannen befreien!” } \\
\text { "Das sollst du am Kreuze bereuen.” }\end{array}$ & 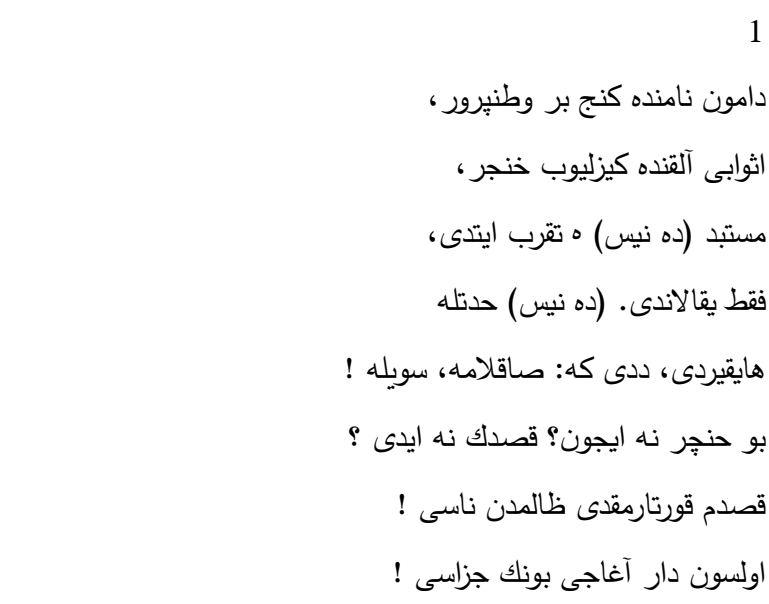 \\
\hline $\begin{array}{l}2 \\
\text { "Ich bin", spricht jener, "zu sterben bereit } \\
\text { Und bitte nicht um mein Leben: } \\
\text { Doch willst du Gnade mir geben, } \\
\text { Ich flehe dich um drei Tage Zeit, } \\
\text { Bis ich die Schwester dem Gatten gefreit; } \\
\text { Ich lasse den Freund dir als Bürgen, }\end{array}$ & 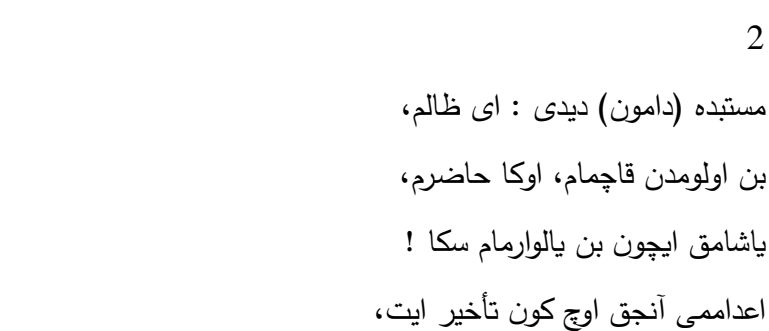 \\
\hline
\end{tabular}
of prose, if only because poetry is now read by a small minority, so that the commercial risks of publishing foreign-looking versions is also less significant." 
An exemplification of domestication: Translation of Friedrich von Schiller's ballad “Die Bürgschaft” into Turkish by Ali Bey Hüseyinzâde (Turan) / A. Uca; F. Soysal (pp. 784-815)

\begin{tabular}{|c|c|}
\hline Ihn magst du, entrinn' ich, erwürgen.” & كه كنر لطف اولسون بكا سندن بو مهلت \\
\hline $\begin{array}{l}3 \\
\text { Da lächelt der König mit arger List } \\
\text { Und spricht nach kurzem Bedenken: } \\
\text { "Drei Tage will ich dir schenken; } \\
\text { Doch wisse, wenn sie verstrichen, die Frist, } \\
\text { Eh' du zurück mir gegeben bist, } \\
\text { So muss er statt deiner erblassen, } \\
\text { Doch dir ist die Strafe erlassen.” }\end{array}$ & 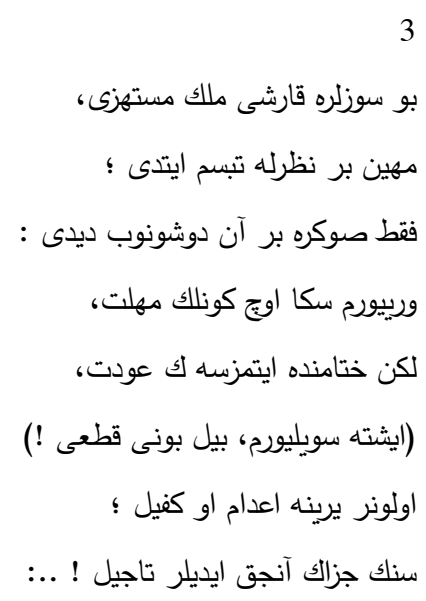 \\
\hline $\begin{array}{l}4 \\
\text { Und er kommt zum Freunde: “Der König gebeut, } \\
\text { Dass ich am Kreuz mit dem Leben } \\
\text { Bezahle das frevelnde Streben. } \\
\text { Doch will er mir gönen drei Tage Zeit, } \\
\text { Bis ich die Schwester dem Gatten gefreit; } \\
\text { So bleib du dem König zum Pfande, } \\
\text { Bis ich komme zu lösen die Bande.” }\end{array}$ & 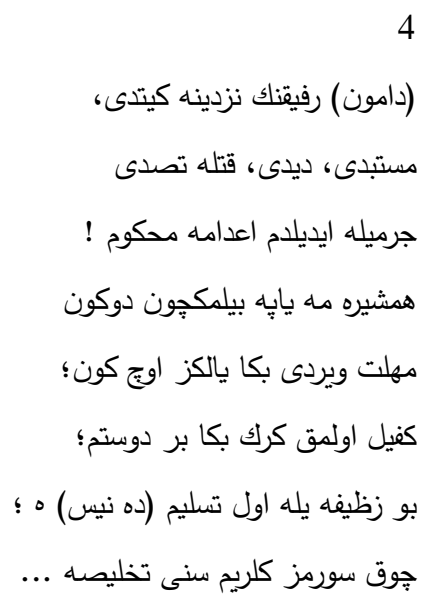 \\
\hline $\begin{array}{l}5 \\
\text { Und schweigend umarmt ihn der treue Freund } \\
\text { Und liefert sich aus dem Tyrannen; } \\
\text { Der andere ziehet von danen. } \\
\text { Und ehe das dritte Morgenrot scheint, } \\
\text { Hat er schnell mit dem Gatten die Schwester vereint, } \\
\text { Eilt heim mit sorgender Seele, } \\
\text { Damit er die Frist nicht verfehle. }\end{array}$ & 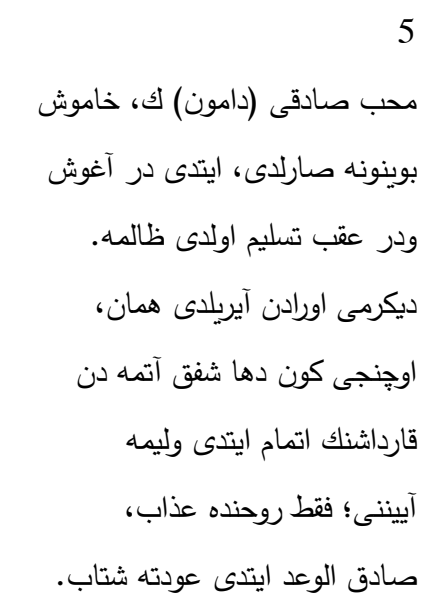 \\
\hline $\begin{array}{l}6 \\
\text { Da giesst unendlicher Regen herab, }\end{array}$ & 6 \\
\hline
\end{tabular}




\begin{tabular}{|c|c|}
\hline $\begin{array}{l}\text { Von den Bergen stürzen die Quellen, } \\
\text { Und die Bäche, die Ströme schwellen. } \\
\text { Und er kommt ans Ufer mit wanderndem Stab, } \\
\text { Da reisset die Brücke der Strudel herab, } \\
\text { Und donnernd sprengen die Wogen } \\
\text { Des Gewölbes krachenden Bogen. }\end{array}$ & 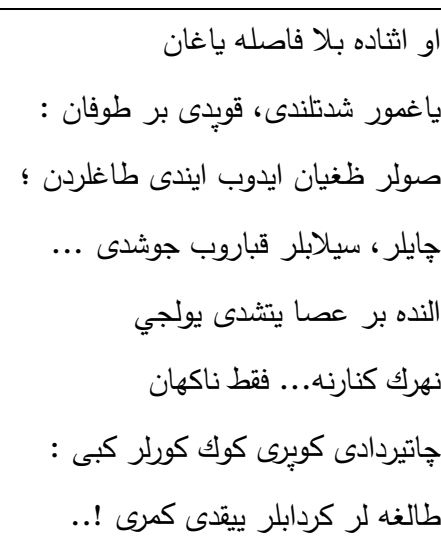 \\
\hline $\begin{array}{l}7 \\
\text { Und trostlos irrt er an Ufers Rand: } \\
\text { Wie weit er auch spähet und blicket } \\
\text { Und die Stimme, die rufende, schicket. } \\
\text { Da stösset kein Nachen vom sichern Strand, } \\
\text { Der ihn setze an das gewünschte Land, } \\
\text { Kein Schiffer lenket die Fähre, } \\
\text { Und der wilde Strom wird zum Meere. }\end{array}$ & 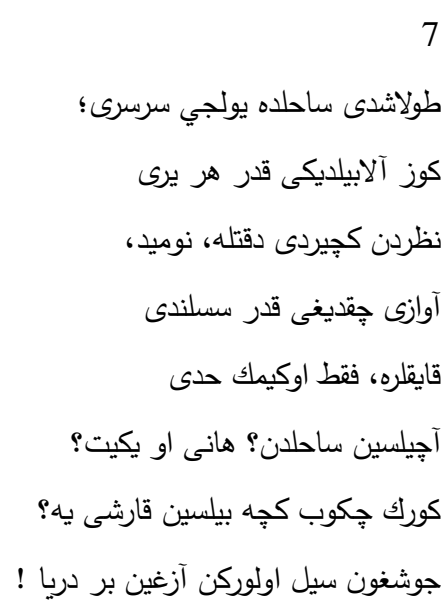 \\
\hline $\begin{array}{l}8 \\
\text { Da sinkt er ans Ufer und weint und fleht, } \\
\text { Die Hände zum Zeus erhoben: } \\
\text { "O hemme des Stromes Toben! } \\
\text { Es eilen die Stunden, im Mittag steht } \\
\text { Die Sonne, und wenn sie niedergeht } \\
\text { Und ich kann die Stadt nicht erreichen, } \\
\text { So muss der Freund mir erbleichen.” }\end{array}$ & 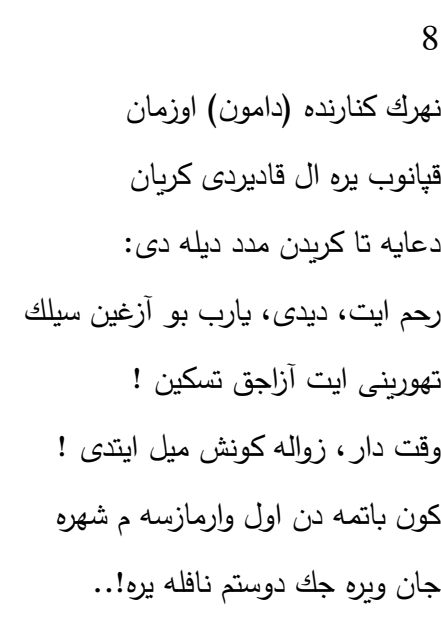 \\
\hline $\begin{array}{l}9 \\
\text { Doch wachsend erneut sich des Stromes Wut, } \\
\text { Und Welle auf Welle zerrinnet, } \\
\text { Und Stunde an Stunde ertrinnet. } \\
\text { Da treibt ihn die Angst, da fasst er sich Mut } \\
\text { Und wirft sich hinein in die brausende Flut } \\
\text { Und teilt mit gewaltigen Armen } \\
\text { Den Strom, und ein Gott hat Erbarmen. }\end{array}$ & 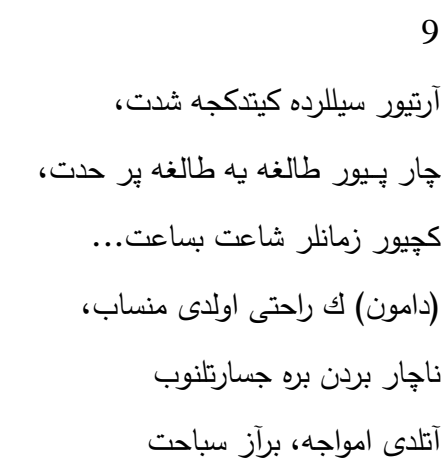 \\
\hline
\end{tabular}


An exemplification of domestication: Translation of Friedrich von Schiller's ballad “Die Bürgschaft” into Turkish by Ali Bey Hüseyinzâde (Turan) / A. Uca; F. Soysal (pp. 784-815)

\begin{tabular}{|c|c|}
\hline & بيليوردى، جليك بازولريله \\
\hline $\begin{array}{l}10 \\
\text { Und gewinnt das Ufer und eilet fort } \\
\text { Und danket dem rettenden Gotte; } \\
\text { Da stürzet die raubende Rotte } \\
\text { Hervor aus des Waldes nächtlichem Ort, } \\
\text { Den Pfad ihm sperrend, und schnaubert Mord } \\
\text { Und hemmet des Wanderers Eile } \\
\text { Mit drohend geschwungener Keule. }\end{array}$ & 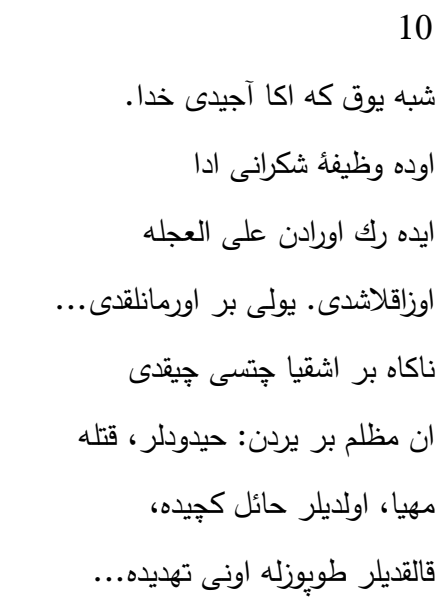 \\
\hline $\begin{array}{l}11 \\
\text { "Was wollt ihr?” ruft er vor Schrecken bleich, } \\
\text { "Ich habe nichts als mein Leben, } \\
\text { Das muss ich dem Könige geben!" } \\
\text { Und entreisst die Keule dem nachsten gleich: } \\
\text { "Um des Freundes willen erbarmet euch!” } \\
\text { Und drei mit gewaltigen Streichen } \\
\text { Erlegt er, die andern entweichen. }\end{array}$ & 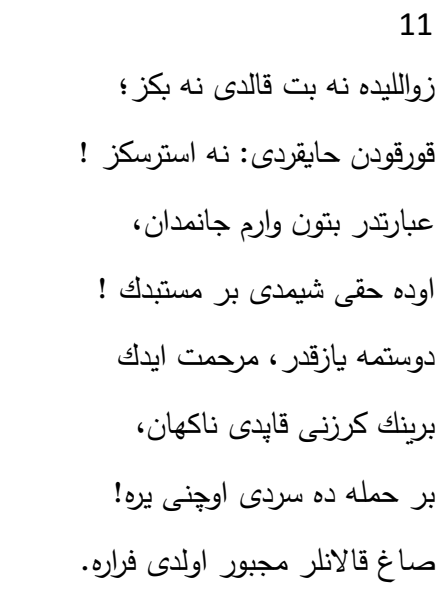 \\
\hline $\begin{array}{l}12 \\
\text { Und die Sonne versendet glühenden Brand, } \\
\text { Und von der unendlichen Mühe } \\
\text { Ermattet sinken die Kniee. } \\
\text { "O hast du mich gnädig aus Räubershand, } \\
\text { Aus dem Strom mich gerettet ans heilige Land, } \\
\text { Und soll hier verschmachtend verderben, } \\
\text { Under der Freund mir, der liebende, sterben!" }\end{array}$ & 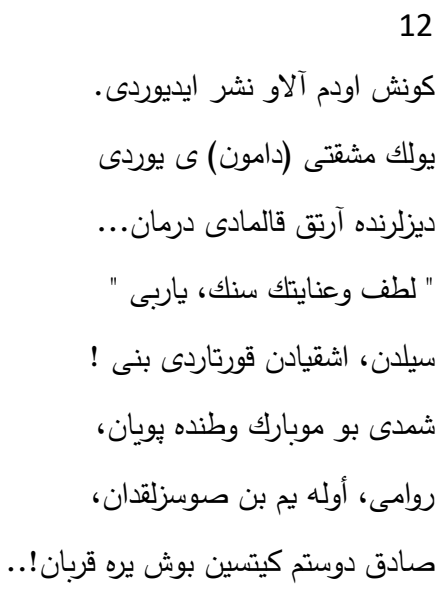 \\
\hline $\begin{array}{l}13 \\
\text { Und horch! da sprudelt es silberhell, } \\
\text { Ganz nahe, wie rieselndes Rauschen, } \\
\text { Und stille hält er, zu lauschen; } \\
\text { Und sieh, aus dem Felsen, geschwätzig, schnell, } \\
\text { Springt murmelnd hervor ein lebendiger Quell, }\end{array}$ & 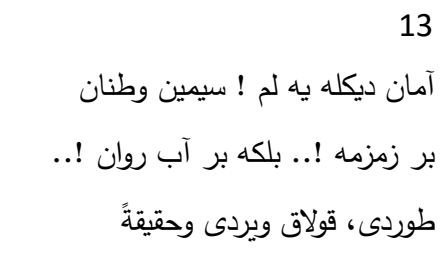 \\
\hline
\end{tabular}




\begin{tabular}{|c|c|}
\hline $\begin{array}{l}\text { Und freudig bückt er sich nieder } \\
\text { Und erfrischet die brennenden Glieder. }\end{array}$ & 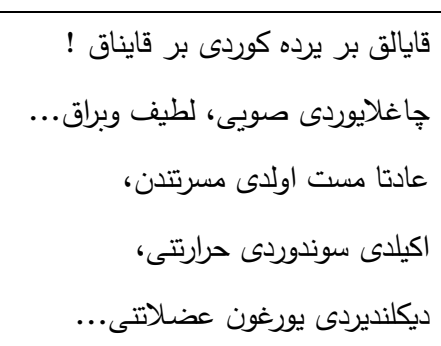 \\
\hline $\begin{array}{l}14 \\
\text { Und die Sonne blickt durch der Zweige Grün } \\
\text { Und malt auf den glänzenden Matten } \\
\text { Der Bäume gigantische Schatten; } \\
\text { Und zwei Wanderer sieht er die Strasse ziehn, } \\
\text { Will eilenden Laufes vorüber fliehn, } \\
\text { Da hört er die Worte sie sagen: } \\
\text { "Jetz wird er ans Kreuz geschlagen." }\end{array}$ & 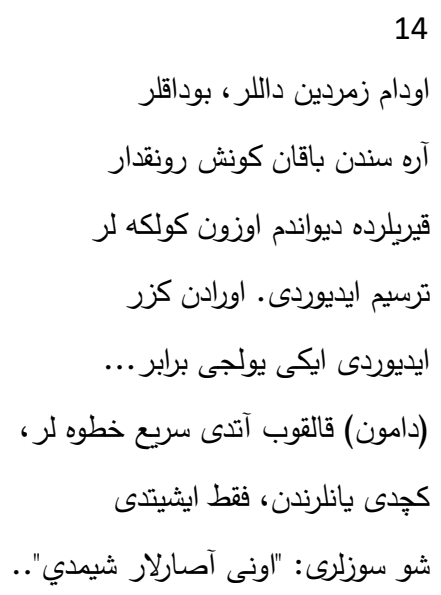 \\
\hline $\begin{array}{l}15 \\
\text { Und die Angst beflügelt den eilenden Fuss, } \\
\text { Ihn jagen der Sorge Qualen; } \\
\text { Da schimmern in Abendrots Strahlen } \\
\text { Von ferne die Zinnen von Syrakus, } \\
\text { Und entgegen kommt ihm Philostratus, } \\
\text { Des Hauses redlicher Hüter, } \\
\text { Der erkennet entsetzt den Gebieter: }\end{array}$ & 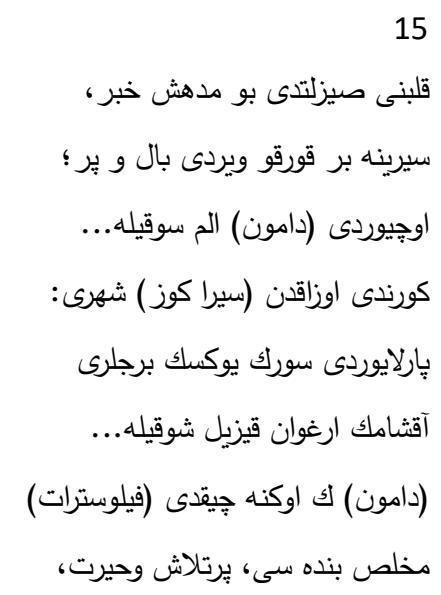 \\
\hline $\begin{array}{l}16 \\
\text { "Zurück! du rettest den Freund nicht mehr, } \\
\text { So rette das eigene Leben! } \\
\text { Den Tod erleidet er eben. } \\
\text { Von Stunde zu Stunde gewartet' er } \\
\text { Mit hoffender Seele der Wiederkehr, } \\
\text { Ihm konnte den mutigen Glauben } \\
\text { Der Hohn des Tyrannen nicht rauben.” }\end{array}$ & 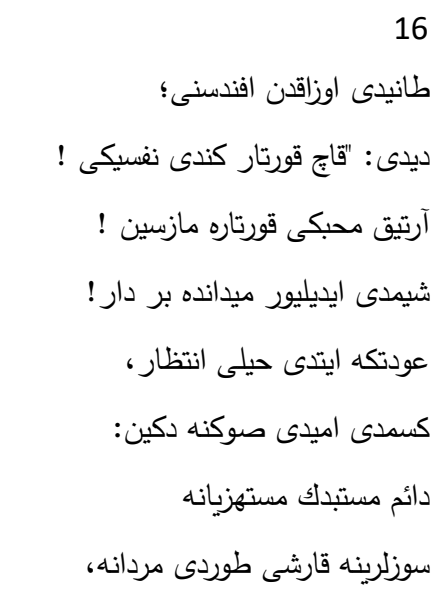 \\
\hline $\begin{array}{l}17 \\
\text { "Und ist es zu spät, und kann ich ihm nicht, }\end{array}$ & 17 \\
\hline
\end{tabular}


An exemplification of domestication: Translation of Friedrich von Schiller's ballad “Die Bürgschaft” into Turkish by Ali Bey Hüseyinzâde (Turan) / A. Uca; F. Soysal (pp. 784-815)

\begin{tabular}{|c|c|}
\hline $\begin{array}{l}\text { Ein Retter, willkommen erscheinen, } \\
\text { So soll mich der Tod ihm vereinen. } \\
\text { Des rühme der blut'ge Tyran sich nicht, } \\
\text { Dass der Freund dem Freunde gebrochen die Pflicht, } \\
\text { Er schlachte der Opfer zweige } \\
\text { Und glaube an Liebe und Treue!" }\end{array}$ & 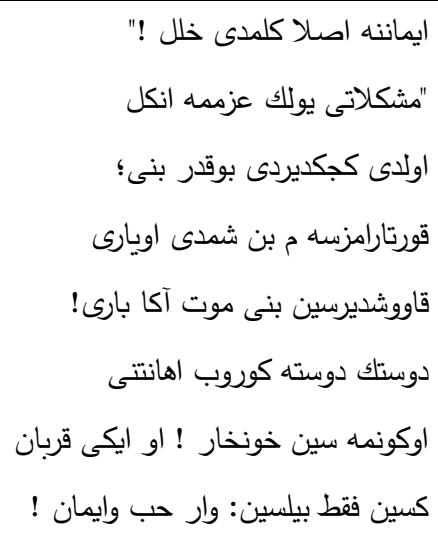 \\
\hline $\begin{array}{l}18 \\
\text { Und die Sonne geht unter, da steht er am Tor, } \\
\text { Und sieht das Kreuz schon erhöhet, } \\
\text { Das die Menge gaffend umstehet; } \\
\text { An dem Seile schon zieht man den Freund empor, } \\
\text { Da zertrennt er gewaltig den dichter Chor: } \\
\text { "Mich, Henker", ruft er, "erwürget! } \\
\text { Da bin ich, für den er gebürget!" }\end{array}$ & 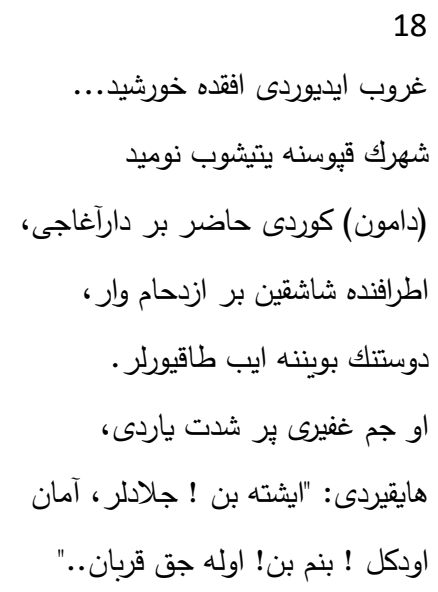 \\
\hline $\begin{array}{l}19 \\
\text { Und Erstaunen ergreifet das Volk umher, } \\
\text { In den Armen liegen sich beide } \\
\text { Und weinen vor Schmerzen und Freude. } \\
\text { Da sieht man kein Augen tränenleer, } \\
\text { Und zum Könige bringt man die Wundermär'; } \\
\text { Der fühlt ein menschliches Rühren, } \\
\text { Lässt schnell vor den Thron sie führen, }\end{array}$ & 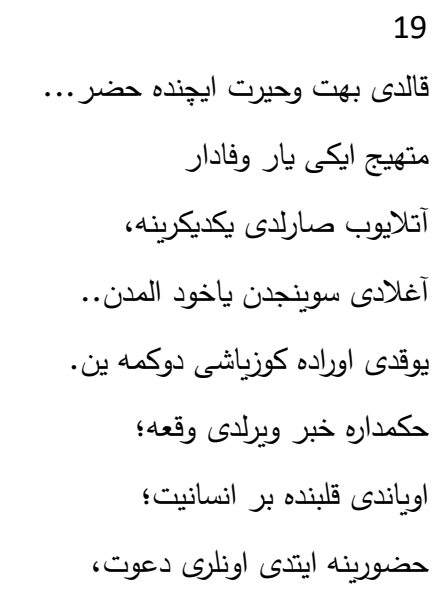 \\
\hline $\begin{array}{l}20 \\
\text { Und blicket sie lange verwundert an. } \\
\text { Drauf spricht er: "Es ist euch gelungen, } \\
\text { Ihr habt das Herz mir bezwungen; } \\
\text { Und die Treue, sie ist doch kein leerer Wahn- } \\
\text { So nehmet auch mich zum Genossen an: } \\
\text { Ich sei, gewährt mir die Bitte, } \\
\text { In eurem Bunde der dritte! }\end{array}$ & 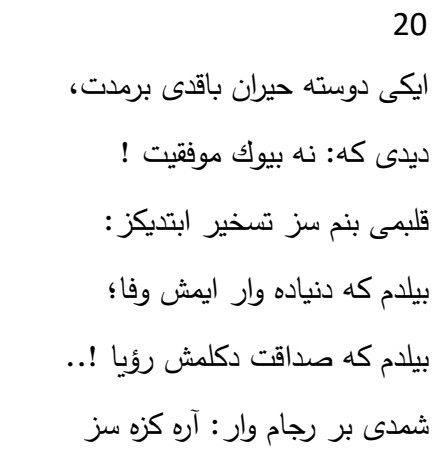 \\
\hline
\end{tabular}




\begin{tabular}{|r|r|}
\hline بنى ده آليكز ! اوله يم مخلص وفاده همبزم ثالث!... & بن \\
\hline
\end{tabular}

\begin{tabular}{|c|c|}
\hline $\begin{array}{l}\text { 4. 3. Erek metin: "Kefalet yahud Vefâdâr } \\
\text { Dost(lar)"7" (Transkripsiyon edilmiş haliyle) } \\
\text { (Çevirmen: Hüseyinzâde Ali Bey (Turan)) }\end{array}$ & $\begin{array}{l}\text { 4. 4. Sunulan alternatif çeviri metin: "Terhin" } \\
\text { (Çeviren: Frrat Soysal) }\end{array}$ \\
\hline $\begin{array}{l}1 \\
\text { Damon namında genç bir vatanperver, } \\
{\text { Esvâb }{ }^{28} \text { altında gizleyip hançer, }} \text { Müstebid }^{29} \text { (Denis) e takarrüb30 etti, } \\
\text { Fakat yakalandı. (Denis) hiddetle } \\
\text { Haykırdı, dedi ki: Saklama, söyle! } \\
\text { Bu hançer ne için? Kastın ne idi? } \\
\text {-Kastım kurtarmaktı zalimden nası! } 3^{11} \\
\text {-Olsun darağacı bunun cezası! }\end{array}$ & $\begin{array}{l}1 \\
\text { Zorba hükümdara, Dionys'e, sinsice } \\
\text { Yaklaştı Damon, giysinin içinde hançeri: } \\
\text { Grubun içindeki hafiye onu patakladı, } \\
\text { "Bu hançerle ne yapmak istedin? Konuș!" } \\
\text { Gözünü kan bulamış kişi kasvetli bir biçimde ona } \\
\text { cevap verir. } \\
\text { "SSehri zorbadan kurtarmaktı niyetim!" } \\
\text { "Çarmığa gerilmek olur bunun bedeli” }\end{array}$ \\
\hline $\begin{array}{l}2 \\
\text { Müstebide (Damon) dedi: Ey zalim, } \\
\text { Ben ölümden kaçmam, ona hazırım, } \\
\text { Yaşamak için ben yalvarmam sana! } \\
\text { İdamımı ancak üç gün tehir et, } \\
\text { Bir lûtf olsun bana senden bu mühlet } \\
\text { Ki tezvic }{ }^{22} \text { edeyim nişanlısına } \\
\text { Hemşiremi;33 dostum zâmin, }{ }^{34} \text { kaçarsam } \\
\text { Kendisini edebilirsin idam!.. }\end{array}$ & $\begin{array}{l}2 \\
\text { O, “ölmeye hazırım” der, } \\
\text { "Ve yaşamım için yalvarmam: } \\
\text { Yine de bana merhamet etmek istiyorsan } \\
\text { Senden üç gün mühlet diliyorum, } \\
\text { Kız kardeşimi everinceye kadar } \\
\text { Dostumu sana rehin olarak bırakıyorum. } \\
\text { Şayet tüyersem, onu sallandırırsın." }\end{array}$ \\
\hline $\begin{array}{l}3 \\
\text { Bu sözlere karşı melik }{ }^{35} \text { müstehzi, }{ }^{36} \\
\text { Mühinin }{ }^{37} \text { bir nazarla tebessüm etti; } \\
\text { Fakat sonra bir an düşünüp dedi: } \\
\text {-Veriyorum sana üç günlük mühlet, } \\
\text { Lakin hitamında }{ }^{8} \text { etmezsen avdet, }{ }^{39} \\
\text { (İşte söylüyorum, bil bunu kati!) } \\
\text { Olunur yerine idam o kefil; } \\
\text { Senin cezan ancak edilir tecil!...40 }\end{array}$ & $\begin{array}{l}3 \\
\text { Bunun üzerine Kral entrikalı bir şekilde gülümser } \\
\text { Ve kısa bir muhakemeden sonra konuşur: } \\
\text { "Sana üç gün mühlet lütfediyorum: } \\
\text { Fakat şunu bil, şayet mühlet sona erer de, } \\
\text { Senden ses çıkmazsa, } \\
\text { Senin yerine o ölmelidir, } \\
\text { Tabii senin cezan da bağışlanır." }\end{array}$ \\
\hline 4 & $\begin{array}{l}4 \\
\text { Ve o dostuna varır: "Kral istiyor, }\end{array}$ \\
\hline
\end{tabular}

159 numaralı (İçtihad) a dercedildikten sonra ayrıca kitap şeklinde basılmıştır.

Esvâb: giysi.

Müstebid: despot, diktatör.

Takarrüb: yaklassma.

Nas: insanlar, halk.

Tezvic: evlendirme.

Hemşire: kız kardeş, abla, bacı.

Zâmin: kefil.

Melik: hükümdar, kral.

Müstehzi: eğlenen, alay eden.

Mühin: hor ve hakir gören.

Hitam: son, nihayet.

Avdet: dönüş, geri gelme.

Tecil: erteleme. 
An exemplification of domestication: Translation of Friedrich von Schiller's ballad “Die Bürgschaft” into Turkish by Ali Bey Hüseyinzâde (Turan) / A. Uca; F. Soysal (pp. 784-815)

\begin{tabular}{|c|c|}
\hline $\begin{array}{l}\text { (Damon) refikinin }{ }^{41} \text { nezdine gitti, } \\
\text { Müstebidi, dedi, katle tasaddi }{ }^{2} \\
\text { Cürmiyle }{ }^{43} \text { edildim idama mahkûm! } \\
\text { Hemşireme yapabilmek için düğün } \\
\text { Mühlet verdi bana yalnız üç gün; } \\
\text { Kefil olmak gerek bana bir dostum; } \\
\text { Bu vazifeyle ol teslim (Denis) e; } \\
\text { Çok sürmez gelirim seni tahlise...44 }\end{array}$ & $\begin{array}{l}\text { Ödememi kanuna karşı gelmenin bedelini } \\
\text { Çarmıhta bitecek hayatımla. } \\
\text { Yine de lütfediyor bana üç gün, } \\
\text { Bir an evvel vermem için kız kardeşimi kocaya; } \\
\text { Kalacaksın bu yüzden sen krala rehin, } \\
\text { Ben gelene kadar prangaları çözmeye.” }\end{array}$ \\
\hline 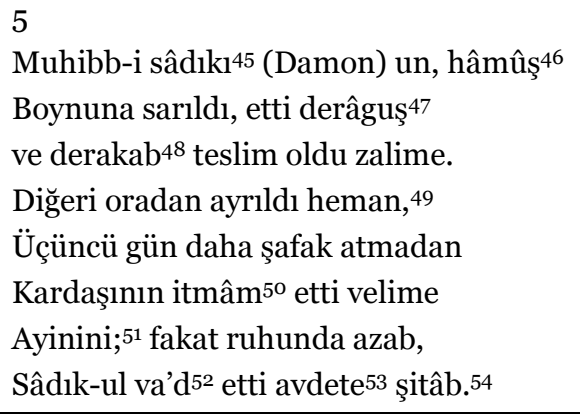 & $\begin{array}{l}5 \\
\text { Ve sadık dostu onu kucaklar, suskundur } \\
\text { Kendisi zorba hükümdara doğru yaklaşır; } \\
\text { Diğeri onlardan uzaklaşır. } \\
\text { Ve üçüncü şafak sökmeden önce, } \\
\text { Kız kardeşini everme işini çarçabuk bitirmiş, } \\
\text { Canla başla acele eder evine, } \\
\text { Verilen süreyi geçirmesin diye. }\end{array}$ \\
\hline $\begin{array}{l}6 \\
\text { O esnada bilâ fâsıla yağan } \\
\text { Yağmur şiddetlendi, koptu bir tufan: } \\
\text { Sular tuğyan } 55 \text { edip indi dağlardan; } \\
\text { Çaylar, seylâbeler }{ }^{6} \text { kabarıp coştu... } \\
\text { Elinde bir asâ57 yetişti yolcu } \\
\text { Nehrin kenarına... Fakat nâ gehan } 58 \\
\text { Çatırdadı köprü gök gürler gibi: } \\
\text { Dalgalar, girdaplar59 yıktı kemeri!..6o }\end{array}$ & $\begin{array}{l}6 \\
\text { O sırada yağar bir yağmur, dinmeyen, bardaktan } \\
\text { boşalırcasına, } \\
\text { Pınarlar fışkırıp akar dağlardan aşağıya, } \\
\text { Ve dereler, nehirler kabarır, } \\
\text { Pekâlâ ulaşır kıyıya elinde gezdirdiği asayla, } \\
\text { O anda bir taşkın köprüyü aşar, } \\
\text { Ve gürleyerek parçalar dalgalar } \\
\text { Kemerin çatırdayan kubbesini. }\end{array}$ \\
\hline $\begin{array}{l}7 \\
\text { Dolaştı sahilde yolcu serseri; }{ }^{61} \\
\text { Göz alabildiği kadar her yeri } \\
\text { Nazardan geçirdi dikkatle, nevmîd, }{ }^{62} \\
\text { Avazı çıktığı kadar seslendi } \\
\text { Kayıklara, fakat o kimin haddi }\end{array}$ & $\begin{array}{l}7 \\
\text { Şaşırır yolunu sahil kıyısında ümitsiz: } \\
\text { Ne kadar uzağı gözlemlese ve incelese } \\
\text { Ve ne kadar uzağa yollasa sesini, çığlığını. } \\
\text { Güvenilir sahilin hiçbir kayığına denk gelmez o vakit, } \\
\text { Onu matlup diyara salıverecek, }\end{array}$ \\
\hline
\end{tabular}

Refik: arkadaş, yoldaş, dost.

Tasaddi: taarruz etmek, bir işe başlamak, kalkışmak.

Cürm: suç, kabahat.

Tahlis: kurtarmak.

Muhibb-i sâdık: sadık dost.

Hâmûș: sessizce.

Derâguş: kucaklamak, sarılmak.

Derakab: hemen, derhal.

Heman: derhal.

İtmâm: tamamlama, bitirme.

Velime ayini: düğün töreni.

Sâdık-ul Va'd: sözünde duran.

Avdet: dönüş, geri gelme.

Şitâb: koşmak, acele etmek.

Tuğyan: aşmak, taşmak, azgınlık.

Seylâb: taşkın su, sel.

Asâ: değnek, baston.

Nâ gehan: birdenbire ansızın.

Girdap: suyun dönerek çukurlaştığı yer, suyun akarak dönmesi.

Kemer: köprünün yay biçiminde üst eşiği.

Serseri: başıboş, çaresiz.

Nevmid: ümitsiz, kederli, cesareti kırılmış. 


\begin{tabular}{|c|c|}
\hline $\begin{array}{l}\text { Açılsın sahilden? Hani o yiğit? } \\
\text { Kürek çekip geçebilsin karşıya? } \\
\text { Coşkun sel olurken azgın bir derya! }\end{array}$ & $\begin{array}{l}\text { Hiçbir kaptan gemileri hareket ettiremez ki, } \\
\text { Ve azgın nehir denize dönüşür. }\end{array}$ \\
\hline $\begin{array}{l}8 \\
\text { Nehrin kenarında (Damon) o zaman } \\
\text { Kapanıp yere el kaldırdı giryân }{ }^{63} \\
\text { Duaya, Tanrı'dan medet diledi: } \\
\text { Rahm et, }{ }^{64} \text { dedi, Ya Rab bu azgın selin } \\
\text { Tehevvürünü }{ }^{65} \text { et azacık }{ }^{66} \text { teskin! }^{67} \\
\text { Vakit dar, zevâle }{ }^{68} \text { güneş meyletti! } \\
\text { Gün batmadan evvel varmazsam şehre } \\
\text { Can verecek dostum nafile yere!.. }\end{array}$ & $\begin{array}{l}8 \\
\text { O esnada sahile çöker, gözyaşı döker ve yakarır, } \\
\text { Ellerini kaldırır Zeus’a açar: } \\
\text { "Ne olur durdur şu firtınalı hengameyi! } \\
\text { Saatler hızla geçmekte, öğlen vaktinde tepede } \\
\text { Güneş ve eğer ki o aşağı inerse } \\
\text { Ve dâhi eğer ben şehre ulaşamazsam, } \\
\text { O dost ölmek zorunda kalacak benim yerime.” }\end{array}$ \\
\hline $\begin{array}{l}9 \\
\text { Artıyor sellerde gittikçe şiddet, } \\
\text { Çarpıyor dalgaya dalga pür hiddet, } \\
\text { Geçiyor zamanlar saat be saat... } \\
\text { (Damon) un rahatı oldu münselib, }{ }^{69} \\
\text { Nâçar }{ }^{70} \text { birdenbire cesaretlenip } \\
\text { Atıldı emvâce, }{ }^{71} \text { biraz sibâhat }{ }^{72} \\
\text { Biliyordu, çelik bâzularıyla }{ }^{73} \\
\text { Yardı seli, çıktı karşı sahile. }\end{array}$ & $\begin{array}{l}9 \\
\text { Aksine artarak sürer firtınalı galeyan, } \\
\text { Ve dalgalar dalgalara karışır, } \\
\text { Ve saatler saatleri kovalar. } \\
\text { Derken kaygı onu mecbur eder, o an cesaretini toplar } \\
\text { Ve atıverir kendini çağlayan taşkın suyun içerisine } \\
\text { Ve yarar kuvvetli kolları ile } \\
\text { Akıntıyı, bir tanrı merhamet sahibi çıkar. }\end{array}$ \\
\hline $\begin{array}{l}10 \\
\text { Şüphe yok ki ona acıdı Hüda. } \\
\text { O da vazife-i şükranı eda } \\
\text { Ederek oradan alelacele } \\
\text { Uzaklaştı. Yolu bir ormanlıktı... } \\
\text { Nâgâh74 bir eşkıya çetesi çıktı } \\
\text { En muzlim }{ }^{75} \text { bir yerden: haydutlar, katle } \\
\text { Müheyya, }{ }^{76} \text { oldular hail77 geçide, } \\
\text { Kalktılar topuzla onu tehdide... }\end{array}$ & $\begin{array}{l}10 \\
\text { Ve karaya ulaşmayı başarır ardından aceleyle fırlar } \\
\text { Ve kurtarıcı tanrıya şükreder; } \\
\text { Çıkagelir o sırada soyguncu çete } \\
\text { Ormandan geceye özgü yerden, } \\
\text { Dar geçitte sıkışır ve burnundan soluyan katil } \\
\text { Ardından engel olur yolcunun süratine } \\
\text { Tehditkâr kavisli gürz ile. }\end{array}$ \\
\hline $\begin{array}{l}11 \\
\text { Zavallıda ne bet kaldı ne beniz; } \\
\text { Korkudan haykırdı: ne istersiniz! } \\
\text { İbarettir bütün varım canımdan, } \\
\text { O da hakkı şimdi bir müstebidin! } \\
\text { Dostuma yazıktır, merhamet edin! } \\
\text { Birinin gürzünü kaptı nâ gehan, }\end{array}$ & $\begin{array}{l}11 \\
\text { "Ne istersiniz?” diye haykırır o korkudan sararmış } \\
\text { halde, } \\
\text { "Canımdan gayri hiçbir şeyim yok } \\
\text { Onu da vermem gerekiyor krala!" } \\
\text { Ve kapar topuzu yanındakinden hemen: } \\
\text { "Dostumun hatırı için merhamet gösterin!" }\end{array}$ \\
\hline
\end{tabular}

63 Giryân: gözyaşı döken, ağlayan.

64 Rahm: acımak, korumak, merhamet etmek.

Tehevvür: yıkıcı gücün en üst mertebesi.

Azack: az, biraz.

Teskin: yatıstırma, suhulet.

Zevâl: son, güneşin batmaya başlaması.

Münselib: rahatsız olmak, rahatı bozulmak.

Nâçar: çaresiz, mecbur kalmış.

Emvâc: dalgalar.

Sibâhat: suda yüzmek.

Bâzu: kolun omuz ile dirsek arasında kalan kısmı.

Nâgâh: aniden, vakitsiz.

Muzlim: karanlık, meçhul.

Müheyya: hazırlanmış.

Hail: perde, engel. 
An exemplification of domestication: Translation of Friedrich von Schiller's ballad “Die Bürgschaft" into Turkish by Ali Bey Hüseyinzâde (Turan) / A. Uca; F. Soysal (pp. 784-815)

\begin{tabular}{|c|c|}
\hline $\begin{array}{l}\text { Bir hamlede serdi üçünü yere; } \\
\text { Sağ kalanlar mecbur oldu firara. }\end{array}$ & $\begin{array}{l}\text { Ve kuvvetli bir darbe ile üçünü } \\
\text { Öldürür, diğerleri oradan sıvsşırlar. }\end{array}$ \\
\hline $\begin{array}{l}12 \\
\text { Güneş o dem }{ }^{78} \text { alev neşrediyordu. } \\
\text { Yolun meşakkati (Damon) u yordu. } \\
\text { Dizlerinde artık kalmadı derman... } \\
\text {-Lûtf u inâyetin }{ }^{79} \text { senin, Ya Rabbi, } \\
\text { Selden, eşkiyadan kurtardı beni! } \\
\text { Şimdi bu mübarek vatanda pûyan, }{ }^{80} \\
\text { Reva mı, öleyim ben susuzluktan, } \\
\text { Sadık dostum gitsin boş yere kurban!.. }\end{array}$ & $\begin{array}{l}12 \\
\text { Ve güneş kızgın ateşini yollar, } \\
\text { Olağanüstü çabanın verdiği } \\
\text { Yorgunlukla dizlerin bağı çözülür. } \\
\text { "Beni haydutların elinden, firtınadan merhamet } \\
\text { ederek, } \\
\text { Kurtaran kutsal toprağa kavuşturan, } \\
\text { Sonrasında bu cehennem sıcağıyla mahvolmalı } \\
\text { mıyım, } \\
\text { Ve fedakâr dostun, yerime ölmesi mi gerekiyor!" }\end{array}$ \\
\hline $\begin{array}{l}13 \\
\text { Aman dinleyelim! Sîminin }{ }^{81} \text { ve tannân } \\
\text { Bir zemzeme!...83 Belki bir âb-1 revân!... } \\
\text { Bi4 } \\
\text { Durdu, kulak verdi ve hakikaten } \\
\text { Kayalık bir yerde gördü bir kaynak! } \\
\text { Çağlıyordu suyu, latif ve berrak... } \\
\text { Adeta mest }{ }^{85} \text { oldu meserretinden, }{ }^{86} \\
\text { Eğildi söndürdü hararetini, } \\
\text { Dinlendirdi yorgun adalâtını... }\end{array}$ & $\begin{array}{l}13 \\
\text { Ve kulak ver! Orada çok yakında, } \\
\text { Tiz bir şekilde şırıl şrıl şırıldar gibi fışkırmakta, } \\
\text { Sus pus ol, kulak kesilmek için: } \\
\text { Ve gör, kayadan, durmadan konuşurcasına, hızlı, } \\
\text { Mırıldanarak fışkırmakta oradan capcanlı bir kaynak, } \\
\text { Ve o sevinçle aşağı eğilir } \\
\text { Ve sıcaktan kavrulan vücudunu serinletir. }\end{array}$ \\
\hline $\begin{array}{l}14 \\
\text { O dem zümrüdin }{ }^{88} \text { dallar, budaklar } \\
\text { Arasından bakan güneş revnakdâr }{ }^{89} \\
\text { Kırlarda dev endam uzun gölgeler } \\
\text { Tersim }{ }^{90} \text { eyliyordu. Oradan güzer } \\
\text { Ediyordu iki yolcu beraber... } \\
\text { (Damon) kalkıp attı seri hatveler,92 } \\
\text { Geçti yanlarından, fakat işitti } \\
\text { Şu sözleri: “Onu asarlar şimdi”.. }\end{array}$ & $\begin{array}{l}14 \\
\text { Ve dalların arasından güneş belirir yeşil } \\
\text { Ve çimlenmiş harikulade meranın üzerinde } \\
\text { Ağaçlar devasa gölgeler; } \\
\text { Ve iki gezgin görür yoldan geçen, } \\
\text { Alelacele koşarak önlerinden geçip gitmek ister, } \\
\text { O sırada onların sarf ettiği sözleri işitir: } \\
\text { "O hali hazırda çarmığa gerilmektedir." }\end{array}$ \\
\hline $\begin{array}{l}15 \\
\text { Kalbini sızlattı bu müthiş haber, } \\
\text { Seyrine bir korku verdi bâl ü per;93 } \\
\text { Uçuyordu (Damon) elem sevkiyle... } \\
\text { Göründü uzaktan (Siragüz) șehri: }\end{array}$ & $\begin{array}{l}15 \\
\text { Ve endişe adımları sıklaştırır; } \\
\text { Istırap veren keder onun yakasını bırakmaz; } \\
\text { O anda gün batımının kzzıllığında parıldar } \\
\text { Uzaktan Siraküza'nın' }{ }^{8} \text { surlarının yükseltisi, }\end{array}$ \\
\hline
\end{tabular}

Dem: zaman, vakit.

İnâyet: yardım.

Puyan: koşan.

Sîmin: gümüşten, gümüşe benzer.

Tannân: uzaklaşan, tınlayan, çınlayan.

Zemzeme: nağme, hoş ses.

Âb-ı revân: akarsu.

Mest: haz duymak.

Meserret: sevinç.

Adalât: adaleler.

Zümrüdin: zümrüt gibi yeșil.

Revnakdâr: parlak, latif, güzel, hoş.

Tersim: resmedilmek, resmini yapmak.

Güzer: geçiş, geçme.

Hatve: adım.

Bal ü per: kol ve kanat.

Siraküza veya Sırakuza, İtalya'nın Sicilya Özerk Bölgesin'de Antik Yunan çağında bir koloni devleti olarak kurulmuş, günümüzde Siracusa ilinin merkezi olan kenttir. (Ç.N.). 


\begin{tabular}{|c|c|}
\hline 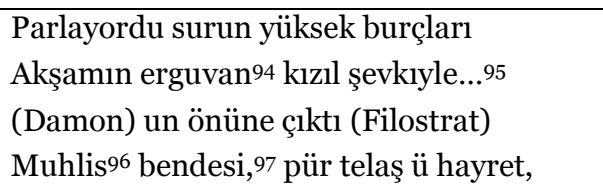 & $\begin{array}{l}\text { Onun karşısına Filostratus }{ }^{99} \text { çıkar, } \\
\text { Hanenin adil bekçisi, } \\
\text { Dehşete kapılmış halde tanır efendisini: }\end{array}$ \\
\hline $\begin{array}{l}16 \\
\text { Tanıdı uzaktan efendisini; } \\
\text { Dedi: "kaç da kurtar kendi nefsini!" } \\
\text { Artık muhibbini }{ }^{100} \text { kurtaramazsın! } \\
\text { Şimdi ediliyor meydanda berdâr!101 } \\
\text { Avdetine etti hayli intizâr, }{ }^{102} \\
\text { Kesmedi ümidi sonuna değin: } \\
\text { Daim müstebidin müstehziyâne }{ }^{103} \\
\text { Sözlerine karşı durdu merdâne, }{ }^{104}\end{array}$ & $\begin{array}{l}16 \\
\text { "Geri dön! Dostunu kurtarman mümkün değil artık, } \\
\text { Bu yüzden kendi canını kurtar! } \\
\text { O pekâlâ ölümü tadacak. } \\
\text { Her saat başı bekleyip durdu } \\
\text { Umudunu kaybetmeden geri dönüşünü ona, } \\
\text { Yürekten inanç onu alıkoyabildi } \\
\text { Zorba hükümdarın küçümsemesinden.” }\end{array}$ \\
\hline $\begin{array}{l}17 \\
\text { İmanına asla gelmedi halel! } \\
\text {-Müşkilâtı }{ }^{105} \text { yolun azmime engel } \\
\text { Oldu, geciktirdi bu kadar beni; } \\
\text { Kurtaramazsam ben şimdi o yari } \\
\text { Kavuştursun beni mevt }{ }^{106} \text { ânâ }{ }^{107} \text { bari! } \\
\text { Dostun dosta görüp ihanetini } \\
\text { Öğünmesin hunhar! }{ }^{108} \mathrm{O} \text {, iki kurban } \\
\text { Kessin fakat bilsin: var hubb }{ }^{109} \text { ve iman!110 }\end{array}$ & $\begin{array}{l}17 \\
\text { "Ve artık çok geç ve ben onun için olamam } \\
\text { Bir kurtarıcı, hoşça gelen karşısına dikilen, } \\
\text { Öyleyse ölüm onunla beni bir araya getirmeli. } \\
\text { Övünmesin kana bulanmış zorba hükümdar, } \\
\text { Dostun dosta taahhüdünü yerine getiremediği için, } \\
\text { Katletsin varsın iki mazlumu } \\
\text { Ve de inansın sevgiye ve sadakate!" }\end{array}$ \\
\hline $\begin{array}{l}18 \\
\text { Gurub }^{111} \text { ediyordu ufukta hurşîd....12 } \\
\text { Şehrin kapısına yetişip nevmid } \\
\text { (Damon) gördü hazır bir darağacı, } \\
\text { Etrafında şaşkın bir izdiham var, } \\
\text { Dostunun boynuna ip takıyorlar. } \\
\text { O cemm-i gafiri113 pür şiddet yardı, } \\
\text { Haykırdı: “İşte ben! Cellâtlar, aman } \\
\text { O değil! Benim ben! Olacak kurban..” }\end{array}$ & $\begin{array}{l}18 \\
\text { Ve güneş batmaktadır, o esnada dikilir şehrin } \\
\text { kapısında o, } \\
\text { Ve görür çarmıh yukarı yükseliyor bile, } \\
\text { Kalabalı şaşkınca etrafını çevirmekte; } \\
\text { Halatlar dostunu artık yukarıya doğru çekmektedir, } \\
\text { O sırada kudretli yoğun bir ses çıkarır: } \\
\text { "Beni, cellat”, diye haykırır, "boğazla! } \\
\text { Ben buradayım, o benim için kefil olmuştu!” }\end{array}$ \\
\hline $\begin{array}{l}19 \\
\text { Kaldı beht }{ }^{114} \text { ve hayret içinde huzzâr... }{ }^{115}\end{array}$ & $\begin{array}{l}19 \\
\text { Ve şaşkınlığa kapılmış halk dört bir yandadır, }\end{array}$ \\
\hline
\end{tabular}

$94 \quad$ Erguvan: eflatunla kırmızı arası renk.

95 Şevk: ışık, parıltı.

$96 \quad$ Muhlis: samimi, sadık, riyasız.

97 Bende: köle, hizmetçi.

99 Philostratus ya da Filostratus, Roma İmparatorluğu döneminde yaşamış olan dört Yunan filozofun adıdır. (Ç.N.).

$100 \quad$ Muhibbi: dost.

101 Berdâr: asılmak, idam edilmek.

102 İntizâr: ümitle beklemek.

103 Müstehziyâne; alay eden, alaycı.

104 Merdâne: mertçe.

105 Müskilât: zorluklar.

106 Mevt: ölüm.

107 Ânâ: ona.

108 Hunhar: zalim

109 Hubb: sevgi.

110 İman: inanç.

111 Gurub: batma.

112 Hurşîd: güneş.

113 Cemm-i gafir: kalabalık, muhafizlar.

114 Beht: şaşkınlık, hayranlık.

115 Huzzâr: ahali, halk; bir yerde ikamet edenler, hazır bulunanlar. 
An exemplification of domestication: Translation of Friedrich von Schiller's ballad “Die Bürgschaft” into Turkish by Ali Bey Hüseyinzâde (Turan) / A. Uca; F. Soysal (pp. 784-815)

\begin{tabular}{|c|c|}
\hline $\begin{array}{l}\text { Müteheyyic }{ }^{116} \text { iki yâr-ı vefâdâr }{ }^{117} \\
\text { Atılıp sarıldı yekdiğerine, } \\
\text { Ağladı sevinçten yahut elemden.. } \\
\text { Yoktu orada gözyaşı dökmeyen. } \\
\text { Hükümdara haber verildi vak’a, }{ }^{118} \\
\text { Uyandı kalbinde bir insaniyet; } \\
\text { Huzuruna etti onları davet, }\end{array}$ & $\begin{array}{l}\text { Kucak kucağa sarılır her ikisi } \\
\text { Gözyaşı dökerler acıdan ve sevinçten. } \\
\text { O anda kimse yoktur ki gözleri dolmasın, } \\
\text { Ve krala bu mucizevi olay iletilir; } \\
\text { Hümanist bir duyarlık hâsıl olur kralda, } \\
\text { Onları çarçabuk huzuruna getirtir, }\end{array}$ \\
\hline $\begin{array}{l}20 \\
\text { İki dosta hayran baktı bir müddet, } \\
\text { Dedi ki: Ne büyük muvaffakiyet!119 } \\
\text { Kalbimi benim siz teshîr120 ettiniz: } \\
\text { Bildim ki dünyada var imiş vefa, } \\
\text { Bildim ki sadakat değilmiş rüya!.. } \\
\text { Şimdi bir ricam var: aranıza siz } \\
\text { Beni de alınız! Olayım muhlis } \\
\text { Bezm-i vefada'121 bir hembezm-i sâlis!.. } \\
\text { (Bayat 1998: } 155^{-161)} \text {. }\end{array}$ & $\begin{array}{l}20 \\
\text { Ve hayran hayran uzun süre onları süzer. } \\
\text { Bunun üzerine konuşur: "Siz başardınız, } \\
\text { Kalbimi ele geçirdiniz; } \\
\text { Ve sadakat, o hiç de boş bir hayal değil- } \\
\text { Beni de dost meclisine kabul edin o halde: } \\
\text { İzin verin, olayım ben de, } \\
\text { Üçüncü bu dostluk bağında! }\end{array}$ \\
\hline
\end{tabular}

\section{5. Örnekler ve inceleme}

Aşağıda inceleme kısmına uygun bir tablo içerisinde, kaynak metinden (KM), sunulan alternatif çeviri metinden (SAÇ) ve Hüseyinzâde Turan'ın çeviri metninden -erek metinden- (EM) alınan örnekler üzerinde çalışmanın amacına yönelik bir çeviri analizi gerçekleştirilmekte; örneklerin incelenmesiyle yerlileştirme stratejisine ilişkin çıkarımlara ulaşlabilmektedir.

Tablo 1: Örnekler ve İnceleme

\begin{tabular}{|c|c|c|c|}
\hline & Kaynak metin (KM) & $\begin{array}{l}\text { Sunulan } \\
\text { çeviri (SAÇ) }\end{array}$ & $\begin{array}{l}\text { Hüzeyinzâde Turan'ın } \\
\text { çevirisi- erek metin (EM) }\end{array}$ \\
\hline 1. & $\begin{array}{l}\text { "Die Bürgschaft" } \\
\text { (Başlık) }\end{array}$ & $\begin{array}{l}\text { "Terhin" } \\
\text { (Başlık) }\end{array}$ & $\begin{array}{l}\text { "Kefalet Yahud Vefadar } \\
\text { Dost(lar)" } \\
\text { (Başlık) }\end{array}$ \\
\hline
\end{tabular}

\footnotetext{
$116 \quad$ Müteheyyic: coşkun, heyecanlı.

117 Yâr-1 vefâdâr: vefakâr dost.

118 Vak'a: mevcut olay.

119 Muvaffakiyet: başarı.

120 Teshîr: büyüleme, itaat ettirme.

121 Bezm-i vefa: vefa grubu, vefa meclisi.

122 Hembezm-i sâlis: üç arkadaş.
} 
"Die Bürgschaft” baladın, yani kaynak metnin, orijinal başlığıdır. Sözlük anlamları itibariyle "kefalet, teminat, garanti, inanca" (Steuerwald 1998: 131), "biri için kefil olma, garanti verme"123 (Pons 20o8: s.y.), "güvence, teminat, garanti, depozito, kefalet, rehin"124 (Wahrig 1998: 207) manalarına gelmektedir. Erek metinde başlık "Kefalet Yahud Vefadar Dost" biçiminde aktarılmış. Kefalet "Birinin borcunu ödememesi veya verdiği sözü yerine getirmemesi durumunda bütün sorumluluğu üzerine alma durumu, kefillik" 125 olarak TDK Sözlüğünde tanımlanmaktadır. Kaynak metinde söz konusu olan, birinin kendisi yerine birisini krala (rehin olarak) bırakmasıdır. Kefillikten ziyade rehine koyma/rehine bırakma vuku bulmaktadır. Bürgschaft'ın manaları arasında hem kefalet hem de rehin ya da rehine bırakma yer almaktadır. Çevirmenin kefalet sözcügünü başlıkta kullanmayı tercih etmesi bu sebepten de kaynaklanıyor olabilir. Ayrıca kefaletin yanında "vefadar dost" ifadesini kullanması, hatta "Kefalet Yahud Vefadar Dost(lar)" şeklinde geniş bir başlık tercih etmesi, hem iki ayrı başlık arasında kararsız kalabildiğinin, dolayısıyla ikisini birden tercih etmiş olabileceğinin hem de baladın -henüz okunmadan önce- okurun aklında bir kefillik ve vefakârlık uyandırması isteğinin sonucu olarak görülebilir. Okura yönelik atıldığı varsayılan ikinci adım, gerek erek kültürde çevirmenin yaratmak istediği etki gerekse başlığın erek kültürde daha anlaşılır kılınması gerekçeleriyle yerlileştirme stratejisine uygun olarak değerlendirilmektedir. Kaynak metnin semantik bütünlüğü açısından çevirmenin tercihte bulunduğu başlık fazlaca bir anlam kaymasına yol açmamış gibi görünmektedir. Yine de alternatif bir çeviri önermek maksadıyla "terhin" sözcüğü erek metin için daha yeterli ve uygun bir başlık olarak sunulabilir. Terhin, "rehin olarak bırakma, rehine koyma, tutuya koyma" ${ }^{126}$ anlamlarına gelmektedir. Dolayısıyla çeviri eşdeğerliğini ve metnin anlamsal bütünlüğünü tümüyle karşıladığı savunulmaktadır.

\begin{tabular}{l|l|l|l} 
2. & $\begin{array}{l}\text { Zu Dionys, dem Tyrannen, schlich } \\
\text { (1. kita 1. dize) }\end{array}$ & $\begin{array}{l}\text { Zorba hükümdara, } \\
\text { Dionys'e, sinsice } \\
\text { (1. kita 1. dize) }\end{array}$
\end{tabular}$\quad \begin{aligned} & \begin{array}{l}\text { Müstebid }{ }^{127} \text { (Denis) e } \\
\text { takarrüb }\end{array} \\
& \text { (1. kita 3. dize) }\end{aligned}$

Dionys (Dionysius) 39 yıl boyunca Tiran olarak Syracuse'ye hükmeden kralın adıdır ${ }^{129}$. EM'de çevirmenin parantez içerisinde Denis olarak nitelendirdiği KM'deki Dionys'tir. Yerlileştirme stratejisi açısından nasıl bir değerlendirmeye tabii tutulacağı tartışlabilir. Ancak çevirmenin yerlileştirme niyetiyle Türkçe okunuşunun erek okurun kulağına uygun gelebileceği “Denis”i tercih etmiş olması muhtemeldir. Çünkü Dionys'in Denis biçiminde bir karşılığına herhangi bir literatürde rastlanamamıştır. Bundan başka, diğer kıtalardaki dizelerde de üzerinde durulduğu üzere, 1. dize EM'de 3. dize olarak karşılığını bulmuştur. Örnekleri incelemeye geçmeden hemen önce burada şu tespite yer vermek gerekir: Çevirmen 7'şer dizelik kıtaları 8'er dizelik kıtalar şeklinde Türkçeye aktardığından KM'nin dizeleri ile EM'nin dizeleri konumları itibariyle birebir örtüşme sağlamamaktadır. Bunun sebebinin yerlileştirme stratejisine uygun bir çeviri gerçekleştirme çabasından kaynaklanmış olabileceği düşünülmektedir.

\begin{tabular}{|l|l|l|l|}
\hline 3. & $\begin{array}{l}\text { "Das sollst du am Kreuze bereuen.« } \\
\text { (1. kita 7. dize) }\end{array}$ & $\begin{array}{l}\text { "Çarmığa gerilmek olur } \\
\text { bunun bedeli” } \\
\text { (1. kita 7. dize) }\end{array}$ & $\begin{array}{l}\text {-Olsun darağacı bunun cezası! } \\
\text { (1. kita 8. dize) }\end{array}$ \\
\hline
\end{tabular}

KM'deki “çarmığa gerilme (am Kreuze bereuen)” nin EM'de “darağacı” ile karşılık bulduğu görülmektedir. Erek kültür düzlemi bakımından darağacı ifadesi daha bilindik ve yerli bir ifadedir. Kültürel ve bilhassa dini açıdan çarmığa gerilme ifadesi tercih sebebi olmamış, dolayısıyla çevirmen tarafından yerlileştirme stratejisine yönelik bir aktarım ortaya koyulmuştur.

\begin{tabular}{|c|c|c|c|}
\hline 4. & $\begin{array}{l}\text { Ich flehe dich um drei Tage Zeit, } \\
\text { Bis ich die Schwester dem Gatten } \\
\text { gefreit; } \\
\text { Ich lasse den Freund dir als Bürgen, } \\
\text { Ihn magst du, entrinn' ich, } \\
\text { erwürgen." } \\
\text { (2. kita 4.-7. dizeler) }\end{array}$ & $\begin{array}{l}\text { Senden üç gün mühlet } \\
\text { diliyorum, } \\
\text { Kız kardeşimi everinceye } \\
\text { kadar } \\
\text { Dostumu sana rehin olarak } \\
\text { bırakıyorum. }\end{array}$ & $\begin{array}{l}\text { İdamımı ancak üç gün tehir et, } \\
\text { Bir lûtf olsun bana senden bu } \\
\text { mühlet } \\
\text { Ki tezvic }^{130} \text { edeyim nişanlısına }\end{array}$ \\
\hline
\end{tabular}

(=Garantie) für jmdn. eine Bürgschaft übernehmen.

Sicherheit, Haftung für jmdn. durch einen Bürgen..

Bkz. https://www.sozluk.gov.tr/ (erişim tarihi: 20.11.2019).

Bkz. https://www.sozluk.gov.tr/ (erişim tarihi: 15.11.2019)

Müstebid: despot, diktatör.

Takarrüb: yaklaşma.

Bkz. Ayr.: http://ozhanozturk.com/2019/02/11/sicilyanin-yunan-tarihi-ve-syracuse-sirakuza-kenti/_(Erişim tarihi: 12.11.2019)

Tezvic: evlendirme. 


\begin{tabular}{|l|l|l|l|}
\hline & & $\begin{array}{l}\text { Şayet tüyersem, onu } \\
\text { sallandırırsı.” } \\
\text { (2. kita 4.-7. dizeler) }\end{array}$ & $\begin{array}{l}\text { Hemşiremi; }{ }^{131} \text { dostum } \\
\text { zâmin, }{ }^{132} \text { kaçarsam } \\
\text { Kendisini edebilirsin idam!.. } \\
\text { (2. kita 4. ve 8. dizeler) }\end{array}$ \\
\hline
\end{tabular}

KM'deki 1. dizenin EM'de 2 dize ile karşılık bulduğu görülmektedir. Çevirmen ilk dizeyi kendi belirlediği 8'lik dize düzenine ulaşmak ve erek kültürel düzlemde açıklayıcı olabilmek adına bu şekilde aktarmış olabilir. Ayrıca “idam” sözcügünü EM'den verilen alıntıdaki ilk ve sonuncu dizelerde tekrarlanması yine erek kültüre yönelik yerli bir ifadenin özellikle vurgulanması olarak değerlendirilmektedir. KM'de 7. dizede geçen ve SAÇ’ta sallandırmak sözcüğüyle metin türü geleneğine bağlı olarak işlevsel bir karşılığı önerilmiş "erwürgen", "boğazlamak, boğmak, boğarak öldürmek"133(Steuerwald 1998: 202) şeklinde Türkçe manalara sahiptir. Çevirmen daha yerli bir karşılık kullanma adına "idam” sözcüğünü tercih etmiştir. Hem başta hem sonda bu sözcüğü vurgulama ihtiyacı ve dolayısıyla serbestîsinde bulunmuştur. Bu yüzden yerlileştirme stratejisine uygun bir çevirmen kararından söz edilebilmektedir.

\begin{tabular}{|l|l|l|l|}
\hline 5. & $\begin{array}{l}\text { Eh' du zurück mir gegeben bist, } \\
\text { So muß er statt deiner erblassen, } \\
\text { Doch dir ist die Strafe erlassen. « } \\
\text { (3. kıta 5. ve 7. dizeler) }\end{array}$ & $\begin{array}{l}\text { Senden ses çlkmazsa, } \\
\text { Senin yerine o ölmelidir, } \\
\text { Tabii senin cezan da } \\
\text { bağışlanır.” } \\
\text { (3. kita 5. ve 7. dizeler) }\end{array}$ & $\begin{array}{l}\text { Lakin hitaminda134 etmezsen } \\
\text { avdet, }{ }^{135} \\
\text { (İşte söylüyorum, bil bunu } \\
\text { kati!) } \\
\text { Olunur yerine idam o kefil; } \\
\text { Senin cezan ancak edilir } \\
\text { tecil!..136 } \\
\text { (3. kita 5. ve 8. dizeler) }\end{array}$ \\
\hline
\end{tabular}

KM'de üç dizelik kısmın EM'de dört dize ile karşılık bulduğu, araya parantez içerisinde ekstra bir dize ile ekleme yapıldığı görülebilir. Ölüm ifadesi ise -yukarıdaki diğer dizelerde olduğu gibi- "idam” ile karşılığını bulmuştur. Cezanın bağışlanması durumunun cezanın tecil edilmesi olarak çevirmen tarafından değerlendirilmiş olması çeviride anlamsal eşdeğerlik açısından yetersiz kalmıştır. Burada anlam kaymasına yol açıldığından dem vurulabilir. Çünkü ertelenmiş ceza halen bekleyen bir ceza durumu yansitırken affedilmiş ceza artık ortadan kalkmış bir duruma referans eder. Dolayısıyla rehin ya da çevirmenin tabiriyle kefil bırakılan dost, Damon'un yerine ölüm cezasına çarptırılacaktır; şayet Damon vaktinde gelemezse. Bu örnekte yerlileştirici unsur olarak EM'de idam karşılığ 1 gösterilebilmekle beraber eklenen fazladan dizenin yapmış olduğu pekiştirici etki ve aynı zamanda açıklayıcı üslubu, hem biçimsel-estetikle ilgili eşdeğerlik açısından hem de baladın kafiyesine sağladığı katkı itibariyle bir çevirmen tercihi olarak görülmektedir. Söz konusu tercihin ise yerlileştirme stratejisine katkı sağlar nitelikte olduğu düşünülmektedir.

\begin{tabular}{|c|c|c|c|}
\hline 6. & $\begin{array}{l}\text { Daß ich am Kreuz mit dem } \\
\text { LebenBezahle das frevelnde } \\
\text { Streben. } \\
\text { (4. kita } 2 \text {. ve } 3 \text {. dizeler) }\end{array}$ & $\begin{array}{l}\text { Ödememi kanuna karşı } \\
\text { gelmenin bedelini } \\
\text { Çarmıhta bitecek } \\
\text { hayatımla. } \\
\text { (4. kıta 2. ve 3. dizeler) }\end{array}$ & $\begin{array}{l}\text { Müstebidi, dedi, katle } \\
\text { tasaddi }{ }^{137} \\
\text { Cürmiyle } \\
\text { mahkûm! (4. kita } 2 \text {. ve } 3 \text {. } \\
\text { dizeler) }\end{array}$ \\
\hline
\end{tabular}

KM’de yer alan “çarmıhta bitecek hayat”, EM’de “idama mahkûm edilme” şeklinde Türkçe karşılığını bulmuş. Çevirmen, çarmıha gerilerek sonlandırılacak suçun cezasını erek kültürde yine suçun karşılığı olarak idama mahkûm edilme durumuyla tasvir etmiştir. Burada erek kültür odaklı ve aynı zamanda yerlileştirici bir çeviri stratejisi benimsendiği söylenebilir. Dini unsurların kültüre, kültürün çevirmene, çevirmenin ise çeviriye etki ettiği erek odaklı ve yerlileştirici zincirin halkaları böylece betimlenebilir. Bilhassa vurgulamak gerekirse, her erek odaklı yaklaşımın yerlileştirme stratejisi güdeceği gibi bir genelleme söz konusu değildir. Bu kıtadaki dizelerin KM'de ve EM'de konum itibari ile diğer kıtalardakinden farklı olarak, aynı konumda olmaları dikkat çekicidir.

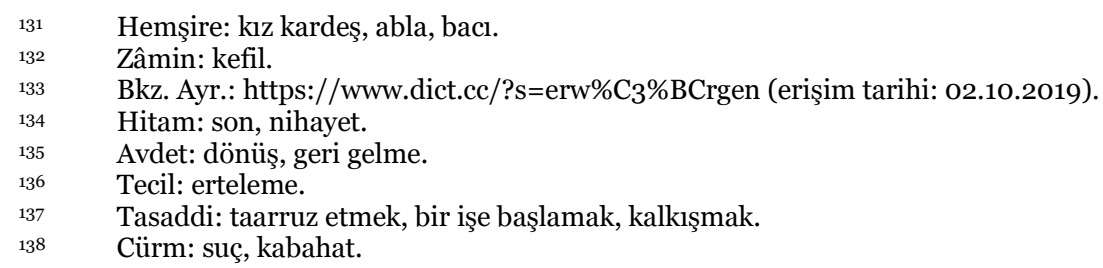




\begin{tabular}{|c|c|c|c|}
\hline 7. & $\begin{array}{l}\text { So bleib du dem König zum Pfande, } \\
\text { Bis ich komme zu lösen die Bande." } \\
\text { (4. kita 6. ve 7. dizeler) }\end{array}$ & $\begin{array}{l}\text { Kalacaksın bu yüzden sen } \\
\text { krala rehin, } \\
\text { Ben gelene kadar prangaları } \\
\text { çözmeye.” } \\
\text { (4. kıta 6. ve 7. dizeler) }\end{array}$ & $\begin{array}{l}\text { Kefil olmak gerek bana bir } \\
\text { dostum; } \\
\text { Bu vazifeyle ol teslim (Denis) } \\
\text { e; } \\
\text { Çok sürmez gelirim seni } \\
\text { tahlise... } \\
\text { (4. kıta } 6 ., \text { 7. ve } 8 \text {. dizeler) }\end{array}$ \\
\hline \multirow{2}{*}{\multicolumn{4}{|c|}{ 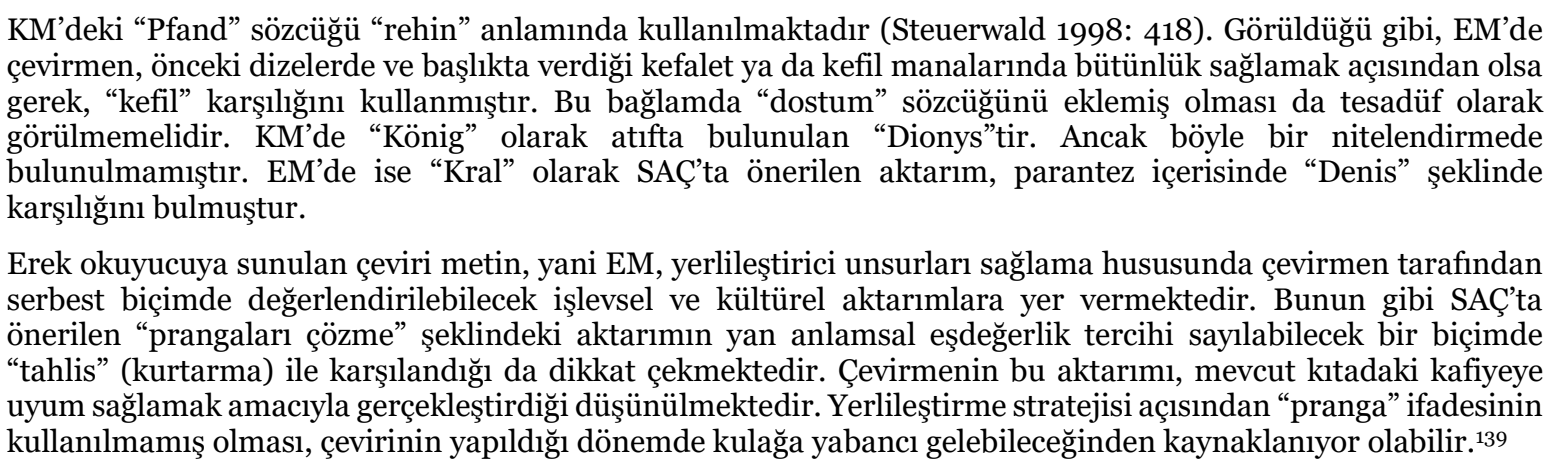 }} \\
\hline & & & \\
\hline 8. & $\begin{array}{l}\text { Hat er schnell mit dem Gatten die } \\
\text { Schwester vereint, }\end{array}$ & $\begin{array}{l}\text { Kız kardeşini everme işini } \\
\text { çarçabuk bitirmiş, }\end{array}$ & $\begin{array}{l}\text { Kardaşının itmâm }{ }^{140} \text { etti } \\
\text { velime }\end{array}$ \\
\hline & $\begin{array}{l}\text { Eilt heim mit sorgender Seele, } \\
\text { Damit er die Frist nicht verfehle. } \\
\text { (5. kita 5.-7. dizeler) }\end{array}$ & $\begin{array}{l}\text { Canla başla acele eder } \\
\text { evine, } \\
\text { Verilen süreyi geçirmesin } \\
\text { diye. } \\
\text { (5. kita } 5 .-7 . \text { dizeler) }\end{array}$ & $\begin{array}{l}\text { Ayinini; }{ }^{141} \text { fakat ruhunda azab, } \\
\text { Sâdık-ul va'd }{ }^{142} \text { etti avdete }{ }^{143} \\
\text { şitâb. }{ }^{144} \\
\text { (5. kita 6.-8. dizeler) }\end{array}$ \\
\hline \multicolumn{4}{|c|}{ 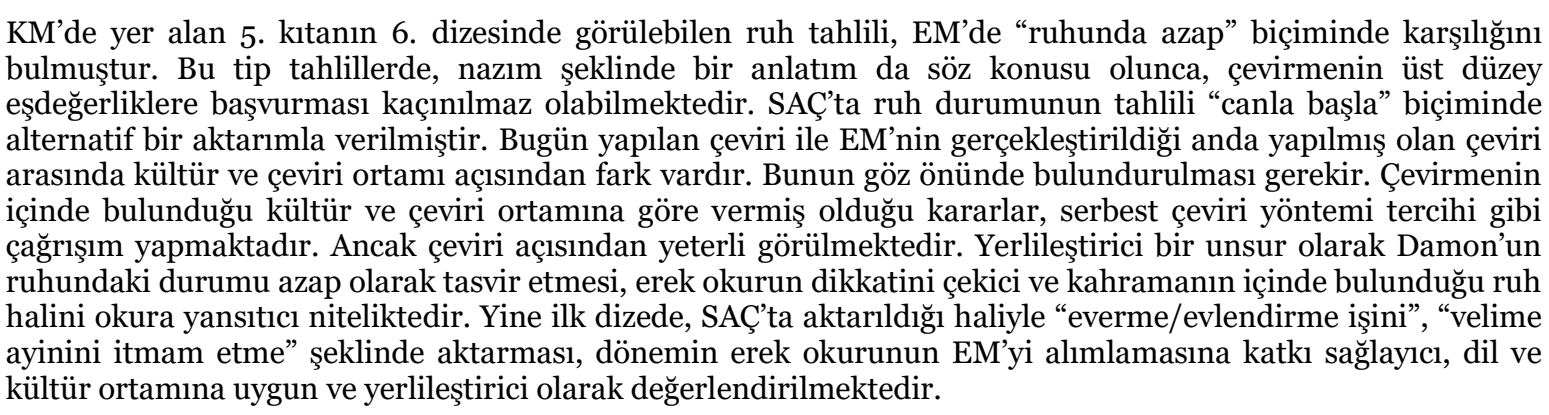 } \\
\hline 9. & $\begin{array}{l}\text { Die Hände zum Zeus erhoben: } \\
\text { »O hemme des Stromes Toben! } \\
\text { (8. kita 2. ve 3. dizeler) }\end{array}$ & $\begin{array}{l}\text { Ellerini kaldırır Zeus'a açar: } \\
\text { "Ne olur durdur şu firtınalı } \\
\text { hengâmeyi! } \\
\text { (8. kıta 2. ve 3. dizeler) }\end{array}$ & $\begin{array}{l}\text { Kapanıp yere el kaldırdı } \\
\text { giryân }^{145} \\
\text { Duaya, Tanrı'dan medet } \\
\text { diledi: } \\
\text { Rahm et, }{ }^{146} \text { dedi, Ya Rab bu } \\
\text { azgın selin }\end{array}$ \\
\hline
\end{tabular}

139 Elbette bu, daha detaylı tarihi bir araştırma neticesinde netlik kazanabilir. Bu türden bir araştırma, mevcut çalışmanın amacı ve kapsamı dışında kalmakla birlikte kapasitesini de aşacaktır. İleri araştırmalar açısından fikir verebilir, konu edilebilir.

140 İtmâm: tamamlama, bitirme.

$141 \quad$ Velime ayini: düğün töreni.

142 Sâdık-ul Va'd: sözünde duran.

143 Avdet: dönüş, geri gelme.

144 Sitâb: kosmak, acele etmek.

145 Giryân: gözyaşı döken, ağlayan.

146 Rahm: acımak, korumak, merhamet etmek. 
An exemplification of domestication: Translation of Friedrich von Schiller's ballad “Die Bürgschaft” into Turkish by Ali Bey Hüseyinzâde (Turan) / A. Uca; F. Soysal (pp. 784-815)

\begin{tabular}{|l|l|l|l|}
\hline & & & $\begin{array}{l}\text { Tehevvürünü147 et azacık }{ }^{148} \\
\text { teskin!149 } \\
\text { (8. kıta 2.- 5. dizeler) }\end{array}$ \\
\hline
\end{tabular}

8. kıtadaki 2. ve 3. dizelerin çevirmen tarafından EM’ye aktarımları gerek yerlileştirme stratejisi gerek serbest çeviri stratejisinden yararlanılarak sağlanan kafiye düzeni açısından oldukça dikkat çeken örnekler arasındadır. Öncelikle KM'nin 2. ve 3. dizelerinin konumları itibariyle EM'de 2., 3., 4. ve 5. dizelere denk geldiğini vurgulamak gerekir. Bununla birlikte çevirmen 2 dize olan KM'den alıntılanan örnekleri, EM'ye 4 dize şeklinde aktararak 8. kıtaya fazladan 2 dize daha eklemiş olmaktadır. KM’nin çevirisinin yapılması açısından böyle bir ekleme yapma zorunluluğuna gerek olmadığı düşünülmektedir. Yerlileştirme stratejisi bağlamında ise çevirmenin birtakım unsurları erek kültüre yabancı gelmemesi, erek okur tarafindan tuhaf karşılanmaması açısından yerli unsurlara dönüştürme gereği duymuş olduğu, bu sebepten aktarıma eklemelerde bulunmuş olduğu görülebilmektedir. KM’de ellerini “Zeus'a” kaldıran kahramanın, EM'de yere kapanarak ellerini “Tanrıya” kaldırdığı, hatta gözyaşı içerisinde dua ederek medet umduğu şeklindeki bir betimleyici ve yerlileştirici aktarımla karşı karşıya kalınmaktadır. Zeus, Tanrı olarak aktarılmış, Zeus’a yalvaran eller, Tanrıya gözyaşıyla yakarmaya, bir bakıma secde haline dönüştürülmüştür (yere kapanma secdeye kapanma manasında düşünüldüğünde). 3. dizede KM'de kahramanın tanrılardan bir tanrı olan Zeus'a firtınayı dindirmesi için yalvarması söz konusuyken EM'de 4. dizede Tanrı artık daha da yerli bir ifade ile Rab’a dönüştürülmüş, yalvarma biçimi rahmet etme (merhamet etme) ifadesiyle karşılanmıştır. Fırtına ise yıkıcı sel ve insanın üstesinden gelemeyeceği yıkıcı bir güç olarak gösterilmiştir. Böylece Rab'dan azıcık dahi olsa bunu dindirebilmesi için duaya kapanan bir kahraman erek okura yansıtılabilmiştir. Tüm bu yerlileştirici unsurların EM'de sağlanabilmesi, çevirmenin başvurduğu serbest çeviri stratejisi ile kültürel, dilsel ve teolojik düzlemde verdiği kararlarla bağlantılıdır. Bir bakıma çok tanrılı bir inanışa sahip kahraman, EM'de tek tanrılı bir din mensubu olarak aktarılmıştır, denebilir. Sonuç itibariyle ortaya çıkan metin tamamen erek okur açısından yerlileştirilmiştir. Çevirmenin başvurduğu eşdeğerlikler ise yerlileştirme uğruna tercih edilen edimsel ve biçimsel eşdeğerlik türleri olarak değerlendirilebilir.

\begin{tabular}{|c|c|c|c|}
\hline 10. & $\begin{array}{l}\text { Und wirft sich hinein in die } \\
\text { brausende Flut } \\
\text { Und teilt mit gewaltigen Armen } \\
\text { Den Strom, und ein Gott hat } \\
\text { Erbarmen. } \\
\text { (9. kita 5. -7. dizeler) }\end{array}$ & $\begin{array}{l}\text { ve atıverir kendini çağlayan } \\
\text { taşkın suyun içerisine } \\
\text { ve yarar kuvvetli kolları ile } \\
\text { Akıntıyı, bir tanrı } \\
\text { merhamet sahibi çıkar. } \\
\text { (9. kıta 5. -7. dizeler) }\end{array}$ & $\begin{array}{l}\text { Nâçar'150 birdenbire } \\
\text { cesaretlenip } \\
\text { Atıldı emvâce, }{ }^{151} \text { biraz } \\
\text { sibâhat }{ }^{152} \\
\text { Biliyordu, çelik bâzularıyla }{ }^{153} \\
\text { Yardı seli, çıktı karşı sahile. } \\
\text { (9. kıta 6. -8. dizeler) }\end{array}$ \\
\hline
\end{tabular}

Çevirmen, KM’den biraz serbest kalarak kahramanın çaresizliğini "naçar” sözcüğü ile EM’ye yansıtmıştır. Son dizede geçen "bir tanrının merhamet sahibi çıkması" tarzındaki anlatıma EM'de yer verilmediği dikkat çekmektedir. O ifadenin yerine çevirmen "karşı sahile çıktı" şeklinde bir yorum getirmiş ve böylece hem eksiltmede hem de eklemede bulunmuştur. Bu durum çeviri eşdeğerliği açısından ele alınabilïr. Bu noktada düz ve yan anlamsal eşdeğerliklerden kaçınılmış olduğu söylenebilir. Asıl inceleme amacı olan yerlileştirme stratejisi açısından ise tanrılar arasından bir tanrının merhamet sahibi olması, çoğunlukla tek tanrılı bir din inancına sahip erek okura tuhaf/yabancı gelebileceğinden olsa gerek, EM'de Türkçe karşılı̆̆ını bulmamış olduğu görülmektedir.

\begin{tabular}{|l|l|l|l|}
\hline 11. & $\begin{array}{l}\text { Und gewinnt das Ufer und eilet fort } \\
\text { Und danket dem rettenden Gotte; } \\
\text { (10. kıta 1. ve 2. dizeler) }\end{array}$ & $\begin{array}{l}\text { ve karaya ulaşmayı başarır } \\
\text { ardından aceleyle firlar } \\
\text { ve kurtarıcı tanrıya } \\
\text { şükreder; } \\
\text { (10. kita 1. ve 2. dizeler) }\end{array}$ & $\begin{array}{l}\text { Şüphe yok ki ona acıdı Hüda. } \\
\text { O da vazife-i şükranı eda } \\
\text { Ederek oradan alelacele } \\
\text { (10. kıta 1. ve 3. dizeler) }\end{array}$ \\
\hline
\end{tabular}

\footnotetext{
147 Tehevvür: yıkıcı gücün en üst mertebesi.

148 Azacik: az, biraz.

149 Teskin: yatıştırma, suhulet.

150 Nâçar: çaresiz, mecbur kalmış.

151 Emvâc: dalgalar.

152 Sibâhat: suda yüzmek.

153 Bâzu: kolun omuz ile dirsek arasında kalan kısmı.
} 
Erek kültür odaklı ve bilhassa dini manada tercih edilen yerlileştirme stratejisi açısından çevirmenin ilk dizede "şüphe yok ki ona acıdı Hüda" şeklindeki aktarımı görülmektedir. KM'de onu kurtaran Tanrıya şükreder kahraman. EM'de ise Tanrı, Hüda sözcüğü ile karşılanarak Hüda'nın kahramana acıması eklenmiş ve vurgu yapılmıştır; sonrasında şükretme eylemi erek okura "vazife-i şükranı eda" ifadesiyle EM'de sunulmuştur. Çevirmen adeta, şükretmenin kulluğun bir vazifesi olduğunu burada vurgulayarak balatın şiirselliğindeki epik unsurları yerlileştirme vasıtasıyla haddinden fazla (KM'de bu dereceye kadar vurgulanmamış olduğu görülebilir) yansıtmış gibidir. Bu şekildeki yerlileştirici çeviriye ait olduğu tespit edilebilen unsurlar ve vurguyu artıran eklenmiş ifadeler nedeniyle 2 dize ile KM'de yer alan kısım EM'de 3 dize ile aktarılmıştır.

\begin{tabular}{|c|c|c|c|}
\hline 12. & $\begin{array}{l}\text { »Ich habe nichts als mein Leben, } \\
\text { Das muß ich dem Könige geben!« } \\
\text { (11. kıta, 2. ve } 3 . \text { dizeler) }\end{array}$ & $\begin{array}{l}\text { "Canımdan gayri hiçbir } \\
\text { şeyim yok } \\
\text { Onu da vermem gerekiyor } \\
\text { krala!" } \\
\text { (11. kıta, 2. ve } 3 \text {. dizeler) }\end{array}$ & $\begin{array}{l}\text { İbarettir bütün varım } \\
\text { canımdan, } \\
\text { O da hakkı şimdi bir } \\
\text { müstebidin! } \\
\text { (11. kıta, 3. ve 4. dizeler) }\end{array}$ \\
\hline
\end{tabular}

KM’de geçen “König”, kahramanın dostunu rehin olarak bıraktığı "kral”dır. Sözcük manası da bu yöndedir. Çevirmenin bu sözcüğ̈ EM’ye "müstebid” ile aktardığı görülmektedir. Müstebid sözcüğü despot manasında kullanıldığından kralın despot bir yönetim anlayışında olduğu izlenimini vermektedir. Baladın anlamsal bütünlüğü kapsamında bunun tutarlı bir yaklaşım olduğu söylenebilir. Yerlileştirici bir çeviri maksadı arandığında ise çevirmenin erek okura kaynak metindeki durumu daha fazla anlatmak ve erek kültürde mevcut yönetimin başında olan kişi ya da kurumun (padişahın vb. yöneticilerin) despot olarak nitelendirilmesinin önüne geçme niyeti olduğu düşünülebilir. Erek okur açısından bakıldığında aynı maksatla tam tersi bir izlenim de bırakılmış olabilir. Çünkü erek kültürün o anki yönetim anlayışında despotluk söz konusu ise bu sefer erek okur balattaki kralda, yani despotta, kendi durumlarını göreceklerdir. Tüm bu çıarımlar neticesinde çevirmenin işlevsel eşdeğerlikle birlikte bir yerlileştirme stratejisini bu dizelerde uygulamış olduğu iddia edilmektedir.

\begin{tabular}{|c|c|c|c|}
\hline 13. & $\begin{array}{l}\text { »O hast du mich gnädig aus } \\
\text { Räubershand, } \\
\text { Aus dem Strom mich gerettet ans } \\
\text { heilige Land, } \\
\text { Und soll hier verschmachtend } \\
\text { verderben, } \\
\text { Und der Freund mir, der liebende, } \\
\text { sterben! « } \\
\text { (12. kita } 4 \text {. ve 7. dizeler) }\end{array}$ & $\begin{array}{l}\text { "Beni haydutların elinden, } \\
\text { firtınadan merhamet } \\
\text { ederek, } \\
\text { Kurtaran kutsal toprağa } \\
\text { kavuşturan, } \\
\text { Sonrasında bu cehennem } \\
\text { sicağıly mahvolmalı } \\
\text { mıyım, } \\
\text { ve fedakâr dostun, yerime } \\
\text { ölmesi mi gerekiyor!" } \\
\text { (12. kıta 4. ve } 7 \text {. dizeler) }\end{array}$ & $\begin{array}{l}\text {-Lûtf u inâyetin }{ }^{154} \text { senin, Ya } \\
\text { Rabbi, } \\
\text { Selden, eşkıyadan kurtardı } \\
\text { beni! } \\
\text { Şimdi bu mübarek vatanda } \\
\text { pûyan, } 155 \\
\text { Reva mı, öleyim ben } \\
\text { susuzluktan, } \\
\text { Sadık dostum gitsin boş yere } \\
\text { kurban!.. } \\
\text { (12. kıta 4. ve } 8 \text {. dizeler) }\end{array}$ \\
\hline
\end{tabular}

EM’nin 12. kıtası 4. dizesinde, buradaki örnekte ilk dizede, Rabbe karşı bir dua ve şükür ile seslenme söz konusudur. Hemen akabinde gelen dizelerde Rabden istenen kahramanın düştüğü durumdan onu kurtarmasıdır. Anlamsal eşdeğerlikler açısından KM ile EM arasında bir uyuşmazlık olduğu iddia edilemez. Ancak EM'de çevirmenin bilhassa Rab olarak seslendiği tanrı modeli ile KM'de hissedilebilen (geçen denilemez çünkü tanrıya dair bir ifade KM'de yer almamaktadır) tanrı modeli aynı varlığa işaret etmemektedir. KM'de kahraman belki Zeus'a, belki de tanrılardan bir tanrıya sesleniyor olabilir. Bu çıkarıma önceki dizelerden ulaşılabilmektedir. Dolayısıyla çevirmen yerlileştirme stratejisini burada çevirmen kararı biçiminde uygulamış görünmektedir. Erek kültür ve okur açısından Rabbe dua, şükür veya kendini acındırma durumu kulluk vazifesi gereği görülebileceğinden bu tarzdaki dini yerlileştirme unsurlarına burada da rastlanmaktadır. KM'de son dize EM'de 8. dizeye tekabül etmektedir. Orada rehin bırakılan dostun kahramanın yerine ölmesi/ölme ihtimali dile getirilmiştir. Oysa EM'de bir anlam sapmasına uğrayan bu husus, dostun boş yere kurban edilmesi noktasına taşınmaktadır. Söz konusu hususta eşdeğerlikle ilgili yorumlamalarda bulunulabilir. Örneğin anlamsal eşdeğerlikler açısından çevirmen kendi ortaya koyduğu EM’nin anlamsal ve mantıksal bütünlüğünü sağlamak adına metin türü geleneklerine bağlı ve edimsel eşdeğerlikleri kullanmayı tercih etmiş gibi görünmektedir. Üst düzey eşdeğerlikler olarak nitelendirebileceğimiz bu eşdeğerliklerin tercihi, çevirmenin amacına hizmet edebilecek nitelikte olduğundan işlevsel bir eşdeğerlik anlayışı da buna dahil edilebilir. Bu tarzda üst düzey eşdeğerliklerin kullanılmasının gerekliliği açısından değerlendirme yapılacak olsa örneklerin seçildiği mevcut EM'nin 12. kıtaya kadar sürdürdüğü yerlileştirici ve biraz da serbest çeviri stratejilerinin bir getirisi olduğundan gerekli görülebilir. Başta izlenen strateji bu biçimde olmasaydı gerekliliği de tartışılabilirdi. Çevirmen stratejilerinin çeviri eşdeğerliğine ne denli etki ettiği de bu şekilde vurgulanmış olmaktadır. Yerlileştirme

\footnotetext{
154 İnâyet: yardım

155 Puyan: koşan.
}

Adres

Kırklareli Üniversitesi, Fen Edebiyat Fakültesi, Türk Dili ve Edebiyatı Bölümü, Kayalı Kampüsü-Kırklareli/TÜRKIYYE e-posta: editor@rumelide.com 
An exemplification of domestication: Translation of Friedrich von Schiller's ballad “Die Bürgschaft” into Turkish by Ali Bey Hüseyinzâde (Turan) / A. Uca; F. Soysal (pp. 784-815)

stratejisi bakımından erek okurda boş yere kurban edilebilecek bir dost, yerine ölebilecek bir dosta nazaran daha yerli ve dolayısıyla daha etkili (belki epik açıdan) olarak düşünülebilir. Çevirmenin bu bağlamda bir anlam bükülmesine yine kendi stratejisi aracılığlyla sebebiyet verdiği iddia edilmektedir.

\begin{tabular}{|c|c|c|c|}
\hline 14. & $\begin{array}{l}\text { Und horch! da sprudelt es } \\
\text { silberhell, } \\
\text { Ganz nahe, wie rieselndes } \\
\text { Rauschen, } \\
\text { Und stille hält er, zu lauschen; } \\
\text { Und sieh, aus dem Felsen, } \\
\text { geschwätzig, schnell, } \\
\text { Springt murmelnd hervor ein } \\
\text { lebendiger Quell, } \\
\text { Und freudig bückt er sich nieder } \\
\text { Und erfrischet die brennenden } \\
\text { Glieder. } \\
\text { (13. kita, tüm (7) dizeler) }\end{array}$ & $\begin{array}{l}\text { ve kulak ver! Orada çok } \\
\text { yakında, } \\
\text { Tiz bir şekilde şırıl şırıl } \\
\text { şarıldar gibi fışkırmakta, } \\
\text { Sus pus ol, kulak kesilmek } \\
\text { için: } \\
\text { ve gör, kayadan, durmadan } \\
\text { konuşurcasına, hızlı, } \\
\text { Mırıldanarak fışkırmakta } \\
\text { oradan capcanlı bir kaynak, } \\
\text { ve o sevinçle aşağı eğilir } \\
\text { ve sıcaktan kavrulan } \\
\text { vücudunu serinletir. } \\
\text { (13. kıta, tüm (7) dizeler) }\end{array}$ & $\begin{array}{l}\text { Aman dinleyelim! Sîmin }{ }^{156} \text { ve } \\
\text { tannân }{ }^{157} \\
\text { Bir zemzeme!...158 Belki bir âb- } \\
\text { 1 revân!..159 } \\
\text { Durdu, kulak verdi ve } \\
\text { hakikaten } \\
\text { Kayalık bir yerde gördü bir } \\
\text { kaynak! } \\
\text { Çağlıyordu suyu, latif ve } \\
\text { berrak... } \\
\text { Adeta mest }{ }^{160} \text { oldu } \\
\text { meserretinden, }{ }^{161} \\
\text { Eğildi söndürdü hararetini, } \\
\text { Dinlendirdi yorgun } \\
\text { adalâtını... }{ }^{162} \\
\text { (13. kıta, tüm (8) dizeler) }\end{array}$ \\
\hline
\end{tabular}

EM'de 13. kıtanın çevirmen tarafından tamamıyla geçmiş zaman diliminde Türkçeye aktarılmış olduğu dikkat çekmektedir. KM'de kullanılan ise şimdiki veya geniş zamandır. Geçmiş zaman tercihini gerektirecek bir durum tespitinde bulunulamamıştır. Ama bu tercihin balattaki anlatımı etkilediği söylenmelidir. Erek okur açısından olay hikâyeleştirilmiş biçimde sunulmaktadır. Yerlileştirme stratejisi ile doğrudan ya da dolaylı bir bağlantısı olmadığı dile getirilebilir. Ancak serbest bir çeviri stratejisi izlenmiş olduğu aşikârdır. EM'deki yerlileştirici unsurlara bakılacak olursa, "zemzem, mest olma, hararetini söndürme, yorgun adalât" ifadeleri gösterilebilir. Zemzem, erek kültürel ve erek dinsel bir ifade olarak EM'de yer alırken mest olma durumu, hararetini söndürme ifadeleri daha ziyade yan anlamsal eşdeğerlik ile karşılık bulmuş erek kültürel ve dilsel ifadeler olarak nitelendirilebilir. Zemzem, balata sonradan çevirmen tarafından eklenmiş bir sözcüktür. KM'de dilsel karşıllğ 1 yer almamaktadır. Mest olma ve hararetini söndürme sözcük grupları ise deyimsel ifadelerdir; onlar yan anlamsal eşdeğerliğe başvurularak erek kültürde yerli gösterilmiş ifadelerdir. Yorgun adalâtını dinlendirmesi, yani yorgun kaslarını dinlendirmesi, yine balata EM'de sonradan eklenmiş bir dize olarak yer almaktadır. Çevirmen bu eklemeyi önceki kıtalarda olduğu gibi 8 dizeye tamamlama gereği ile yapmış olabilir. Neticede çevirmen kahramanın yaşadıklarından yola çıkarak yorgun kaslarını dinlendirmesi şeklinde bir yorum getirme girişiminde bulunmuştur. Erek okur açısından yerlileştirici bir unsur teşkil ettiğinden onun bu girişimi söz konusu kıta bağlamında başarılı da olmuştur. Çünkü çevirmenin, anlatımı ile ve kafiyeyi bozmadan üst düzey eşdeğerliklerden biri olan biçimsel-estetik eşdeğerliği sağlayabildiği görülmektedir.

\begin{tabular}{|l|l|l|l}
\hline 15. & $\begin{array}{l}\text { "Jetzt wird er ans Kreuz } \\
\text { geschlagen. } \\
(14 . \text { kita } 7 \text {. dize) }\end{array}$ & $\begin{array}{l}\text { "O hali hazırda çarmığa } \\
\text { gerilmektedir." } \\
\text { (14. kita 7. dize) }\end{array}$ & $\begin{array}{l}\text { Şu sözleri: “Onu asarlar } \\
\text { şimdi”.. } \\
\text { (14. kita 8. dize) }\end{array}$
\end{tabular}

KM’de “ans Kreuz geschlagen” şeklindeki ifade, SAÇ’ta “çarmıha gerilme” eylemiyle karşılığını bulmuş, EM'de ise "asma” eylemine dönüştürülerek aktarılmıştır. Çevirmen daha önceki kıtalarda çoğunlukla karşılaşıldığı gibi burada da yerlileştirme stratejisini erek kültüre ait inanışa / dine göre ve devletin yönetim biçimine yönelik bir ceza yöntemini tercih ederek gerçekleştirmiştir.

\begin{tabular}{|l|l|l|l|}
\hline 16. & $\begin{array}{l}\text { Da schimmern in Abendrots } \\
\text { Strahlen } \\
\text { Von ferne die Zinnen von Syrakus, }\end{array}$ & $\begin{array}{l}\text { O anda gün batımının } \\
\text { kızıllı̆̆ı̆nda parıldar }\end{array}$ & $\begin{array}{l}\text { Göründü uzaktan (Siragüz) } \\
\text { şehri: } \\
\text { Parlayordu surun yüksek } \\
\text { burçları }\end{array}$ \\
\hline
\end{tabular}

Zemzeme: nağme, hoş ses.

Âb-ı revân: akarsu.

Mest: haz duymak.

Meserret: sevinç.

Adalât: adaleler.

Address

Kırklareli University, Faculty of Arts and Sciences, Department of Turkish Language and Literature, Kayalı Campus-Kırklareli/TURKEY e-mail: editor@rumelide.com 


\begin{tabular}{|c|c|c|c|}
\hline & (15. kıta 3. ve 4. dizeler) & $\begin{array}{l}\text { Uzaktan Siraküza’nın }^{163} \\
\text { surlarının yükseltisi, } \\
\text { (15. kıta 3. ve 4. dizeler) }\end{array}$ & $\begin{array}{l}\text { Akşamın erguvan }{ }^{164} \text { kızıl } \\
\text { şevkıyle... }{ }^{165} \\
\text { (15. kıta } 4 . \text { ve } 6 . \text { dizeler) }\end{array}$ \\
\hline \multicolumn{4}{|c|}{ 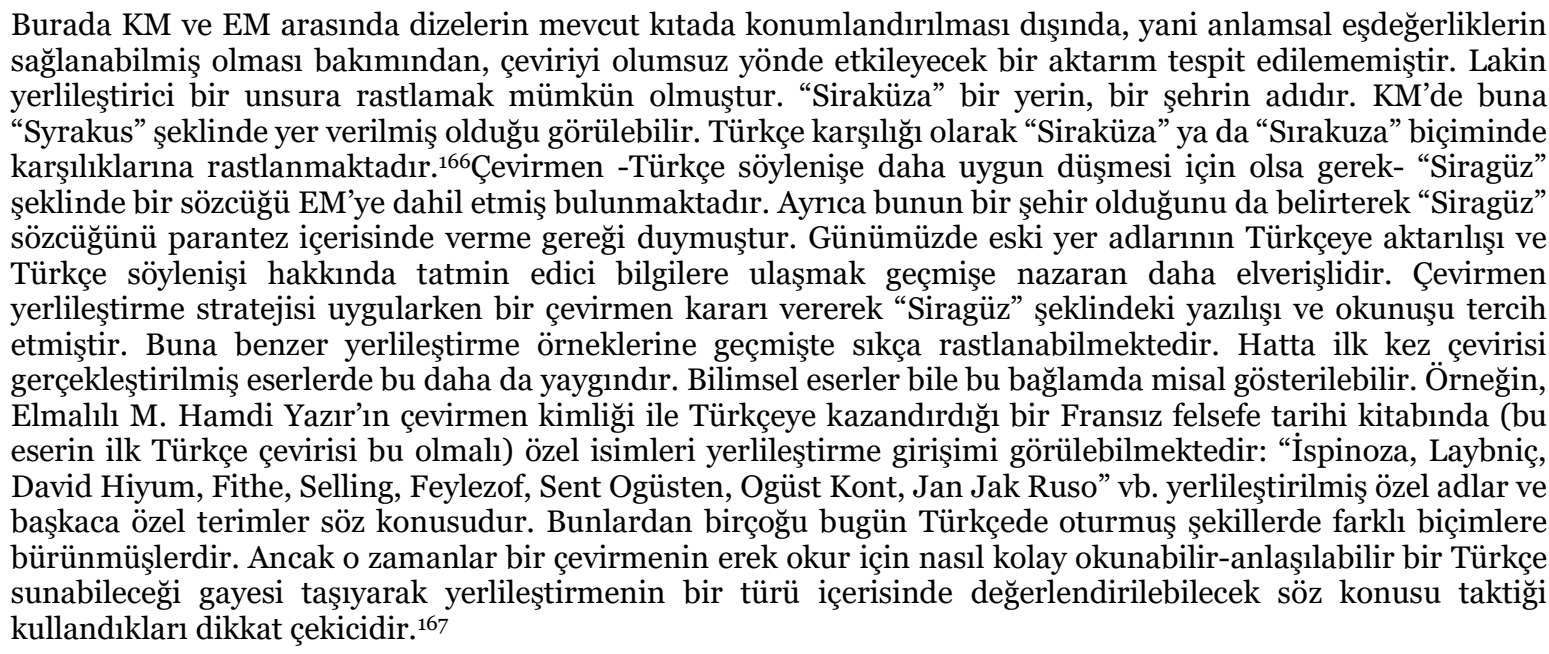 } \\
\hline 17. & $\begin{array}{l}\text { m konnte den mutigen Glauben } \\
\text { r Hohn des Tyrannen nicht } \\
\text { dben.« } \\
\text { kita 6. ve } 7 \text {. dizeler) }\end{array}$ & $\begin{array}{l}\text { Yürekten inanç onu } \\
\text { alıkoyabildi } \\
\text { Zorba hükümdarın } \\
\text { küçümsemesinden.” } \\
\text { (16. kıta 6. ve 7. dizeler) }\end{array}$ & $\begin{array}{l}\text { Daim müstebidin } \\
\text { müstehziyâne }{ }^{168} \\
\text { Sözlerine karşı durdu } \\
\text { merdâne, }{ }^{169} \\
\text { İmanına asla gelmedi halel! } \\
\text { (16. kıta } 7 \text {. ve } 8 \text {. dizeler, } 17 . \\
\text { Kita } 1 \text {. dize) }\end{array}$ \\
\hline \multirow{2}{*}{\multicolumn{4}{|c|}{ 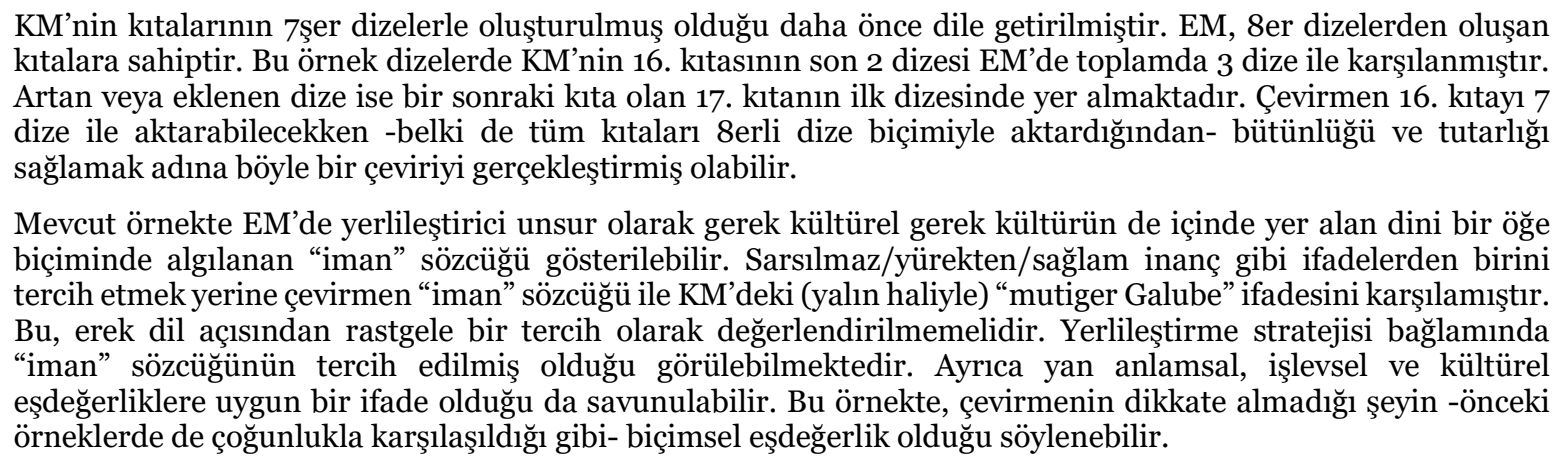 }} \\
\hline & & & \\
\hline 18. & $\begin{array}{l}\text { Und glaube an Liebe und Treue!« } \\
\text { (17. kita } 7 . \text { dize) }\end{array}$ & $\begin{array}{l}\text { Ve de inansın sevgiye ve } \\
\text { sadakate!" } \\
\text { (17. kita } 7 . \text { dize) }\end{array}$ & $\begin{array}{l}\text { Kessin fakat bilsin: var } \\
\text { hubb }{ }^{170} \text { ve iman!171 } \\
\text { (17. kita } 8 \text {. dize) }\end{array}$ \\
\hline
\end{tabular}

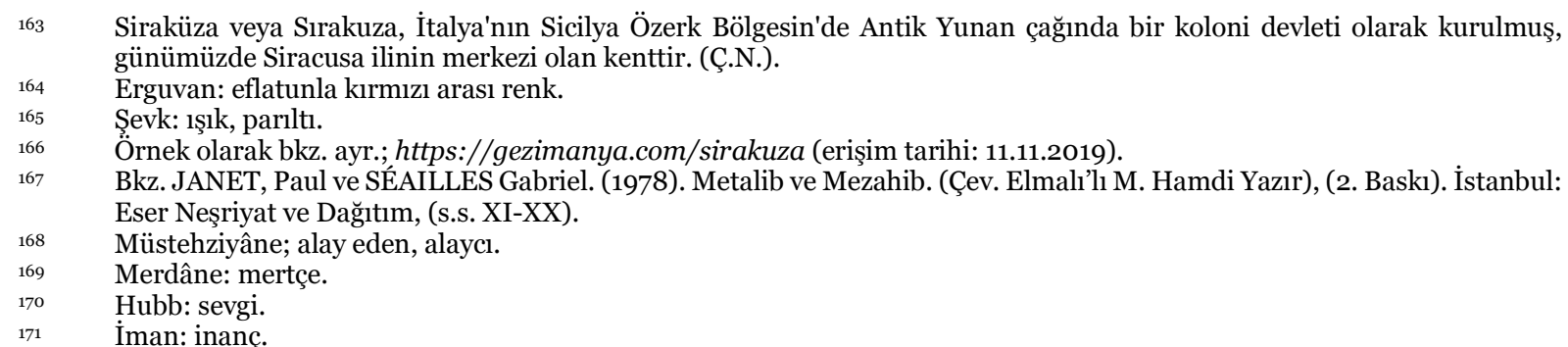


KM’deki "Liebe und Treue" sözcüklerinin EM’ye "hubb ve iman" (sevgi ve iman/(kuvvetli) inanç) biçiminde aktarıldığı görülmektedir. SAÇ’ta önerilen çeviride "sevgi ve sadakat" tercih edilmiştir. "Treue” sözcüğü (düz) anlamsal eşdeğerlik bağlamında "sadakate, vefaya, bağlılığa, sadık olma durumuna" işaret eden bir manaya sahiptir (krş. Steuerwald 1998: 542). Çevirmenin tercih etmiş olduğu "iman" sözcüğü ise inanç ile alakalı manaları içerisinde barındırır. Çevirmen kararında -erek kültürel düzlemde- baş kahramanın imanının gerektirdiğ i bir bağlılık/sadakat düşünülerek erek okura böyle bir karşılık sunulmuş olabilir. Yerlileştirici unsur olarak bu örneğin ele alınmasında böyle bir çıkarımdan hareket edilmiştir. Ayrıca aynı kıtanın ilk dizesinde "iman" sözcüğünü tercih eden çevirmenin son dizede yine "iman" sözcüğü ile kıtayı tamamlaması, kendi oluşturduğu şiirsel ya da stilistik biçimselliği ve estetiği sağlamak amaciyla gerçekleştirilmiş olabilir.

\begin{tabular}{|l|l|l|l}
\hline 19. & $\begin{array}{l}\text { Und sieht das Kreuz schon erhöhet, } \\
\text { (18. kıta 2. dize) }\end{array}$ & $\begin{array}{l}\text { ve görür çarmıh yukarı } \\
\text { yükseliyor bile, } \\
\text { (18. kita 2. dize) }\end{array}$ & $\begin{array}{l}\text { (Damon) gördü hazır bir } \\
\text { darağacı, } \\
\text { (18. kıta 3. dize) }\end{array}$ \\
\hline
\end{tabular}

SAÇ’ta aktarıldı̆̆ı gibi KM'deki “Kreuz” (çarmı), EM'de “darağacı”na, yine KM'deki “erhöhen” fiilinin "yükselme” şeklindeki manası EM’de "hazır (olma)" manasına dönüştürülmüştür. Çevirmen burada yerlileştirme stratejisini bilhassa dini temellere dayalı erek kültürel unsurların kaynak kültürel unsurlarla yer değiștirmesi biçiminde uygulamıştır. Erek kültürde hem devlet yönetim biçimindeki cezalandırmalarda hem de dini yaptırımlarda çarmı kurma, çarmıha germe söz konusu olmadığından yükselen çarmıh erek okurda yabancı/tuhaf bir etki bırakacaktır. Onun yerine hazırlanmış bir darağacı gerek devletin cezai yaptırımı gerek dini cezai yaptırım açısından erek okurun kulağına yerli bir söylem olarak gelecektir.

\begin{tabular}{|c|c|c|c|}
\hline 20. & $\begin{array}{l}\text { An dem Seile schon zieht man den } \\
\text { Freund empor, } \\
\text { (18. kita } 4 . \text { dize) }\end{array}$ & $\begin{array}{l}\text { Halatlar dostunu artık } \\
\text { yukarıya doğru } \\
\text { çekmektedir, } \\
\text { (18. kıta } 4 \text {. dize) }\end{array}$ & $\begin{array}{l}\text { Dostunun boynuna ip } \\
\text { takıyorlar. } \\
\text { (18. kita } 5 \text {. dize) }\end{array}$ \\
\hline \multicolumn{4}{|c|}{$\begin{array}{l}\text { KM'de, SAÇ’ta yer aldığı gibi, halatların yukarıya çekilmesi durumu söz konusudur. Çekilen halatlar baladın } \\
\text { önceki dizelerinde verilmiş olan çarmıhın halatlarıdır. EM'de çevirmen, bir önceki örnekte kaçındığ üzere, } \\
\text { çarmıla bağlantılı anlamsal bir çeviri gerçekleştirmemiş, darağacına atfen rehin birakılmış dostun boynuna } \\
\text { takılan ip biçiminde bir karşılıkla aktarımı sağlamıştır. KM'de çarmığa ait halatların EM'de darağacında boyna } \\
\text { geçirilen ipe dönüşmesi yerlileştirici unsur olarak değerlendirilmektedir. Çevirmen, sözü edilen dizelerde } \\
\text { yerlileştirme stratejisine bu şekilde başvurmuştur. }\end{array}$} \\
\hline
\end{tabular}

21.

$$
\begin{aligned}
& \text { Da bin ich, für den er gebürget!« } \\
& \text { (18. kıta 7. dize) }
\end{aligned}
$$

Ben buradayım, o benim için kefil olmuştu!"

(18. kita 7. dize)
O değil! Benim ben! Olacak kurban.."

(18. kita 8. dize)

KM'de baş kahraman, SAÇ'ta aktarıldığı gibi, dostunun onun yerine kefil olduğunu dile getirmektedir. EM'de söylemin aktarımında biraz farklılıklar görülmekle beraber bilhassa "kefil” sözcügünün "kurban" sözcüğü ile karşılandığı dikkat çekmektedir. Birinin yerine ölmek pahasına kurban olma eyleminin erek kültür ve okur açısından kefil olmaya nazaran daha yerli göründüğünden çevirmenin bu örnekte yine yerlileştirme stratejisine başvurmuş olduğu çıkarıma varılabilir.

\begin{tabular}{|l|l|l|l} 
22. & $\begin{array}{l}\text { Und die Treue, sie ist doch kein } \\
\text { leerer Wahn - } \\
\text { (20. kita 4. dize) }\end{array}$ & $\begin{array}{l}\text { ve sadakat, o hiç de boş bir } \\
\text { hayal değil- } \\
\text { (20. kita 4. dize) }\end{array}$ & $\begin{array}{l}\text { Bildim ki dünyada var imiş } \\
\text { vefa, } \\
\text { Bildim ki sadakat değilmiş } \\
\text { rüya!.. } \\
\text { (20. kita 4. ve 5. dizeler) }\end{array}$ \\
\hline
\end{tabular}

KM'de tek dize halinde yer alan kısım EM’ye 2 dize ile aktarılmıştır. Çevirmen, erek okur açısından baladın son kıtasında didaktik bir vurgu yapma ve/veya kafiye bütünlüğ̈̈ sağlama niyetiyle bu türden bir aktarım tercih etmiş olabilir. Anlamsal eşdeğerlik bakımından yeterli görülebilen bir çeviri söz konusudur. Ancak anlamın haddinden fazla vurgulandığı, eklemelerin yapılmış olduğu ve "Treue" sözcüğünün EM'ye hem "vefa" hem de "sadakat" sözcükleriyle iki kez, adeta üstüne basa basa, aktarıldığı görülmektedir. Nihayetinde erek kültür açısından EM'nin vurgulayıcı, abartılı ve yerlileştirici bir aktarıma sahip olduğu kanaatine varılmaktadır. Yerlileştirici unsur olarak ayrıca çevirmenin kendi kararı ile belirlemiş olduğu 8erlik dizeyi gerçekleştirme gayesi öne sürülen bir diğer husus olmuştur. 


\section{Değerlendirme}

Çalışmada, kaynak ve erek metin üzerinde gerçekleştirilmesi planlanan inceleme için uygun görülen örnekler üzerinde çeviride yerlileştirme unsurları ve bu unsurların çeviri eşdeğerliği açısından nasıl erek metinde yer aldıkları detaylı bir biçimde gösterilmeye çalışılmıştır. Hüzeyinzâde Turan’ın çevirisinin, çeviride yerlileştirme stratejisi açısından oldukça uygun bir çeviri örneği olduğu çıkarımına varılmıştır. Hatta bundan dolayı örneklerin biraz daha artırllabilmesinin mümkün olabileceğini da söylemek gerekir. Ancak inceleme açısından yeterli sayıda görülen örnekler, hedeflenen çıkarımların oluşmasını sağlamış vaziyettedir. Bunlardan sonuç olarak bahsetmek gerekirse; "Kefalet Yahud Vefadar Dost(lar)" başlıklı erek metinde uygulanan yerlileştirme stratejisinin, daha ziyade dini terminolojinin ve milli duygulara ait ifadelerin çevirmen tarafından yerlileştirildiği bir strateji izlenimi verdiğini en başta söylemek gerekir. Çevirinin gerçekleştirildiği dönem ve çevirmen Hüzeyinzâde Turan'ın sahip olduğu şahsi idealleri göz önüne alındığında; başta dini terminolojinin değiştirilerek - bir diğer deyişle Hristiyan ve/veya çok tanrılı Helenist unsurların İslami unsurlarla yer değiştirilerek- yerlileştirildiği, kaynak metnin okuruna aksettirilmek istenen milli duyguların çevirmen tarafından erek okur için yine Türk örf ve kültürüne uygun biçimde yerlileştirilerek ön plana çıarıldı̆̆g örnekler vasıtasıyla tespit edilmiştir. Bunların dışında kalan kültürel, dilsel, didaktik, şiirsi ve üsluba ilişkin birçok unsurun yine çevirmen tarafından yerlileştirme stratejisi ile erek metne aktarıldığını söylemek mümkündür. Bütün bu değerlendirmeler, çalışmanın örnekler üzerinde yürütülen inceleme kısmında detaylıca tartışılmıştır.

Bir çeviri sürecinde, çevirmenin tercih ettiği strateji(ler), aldığı kararlar ve başvurduğu eşdeğerlikler, sürecin tümünü etkileyen çok önemli hususlardır. Bu çalışmada çevirmenin (bilinçli veya bilinçsiz olarak) tercih ettiği yerlileştirme stratejisinin çevirmenin kararlarını etkilediği ve onun başvurduğu eşdeğerliklerde yine belirleyici olduğu görülmüsstür. Birbirine bağlı gerçekleştiği görülen bu etkileşimin altında çevirmenin arka planının / tecrübesinin / yaşanmışlı̆̆ının (Habitus / Erlebnis) da rol oynadığı varılan bir diğer çıkarımdır. Sonuç itibariyle; çeviride stratejinin önemi vurgulanmış, yerlileştirme stratejisinin erek kültür ve okur açısından kaynak metnin anlaşılırlığının sağlanmasında ve aşinalığının oluşturulmasında tercih edilen etkili bir strateji olduğu Hüseyinzâde Turan'ın "Kefalet Yahud Vefadar Dost(lar)" başlıklı çevirisinin incelenmesiyle ortaya koyulmuştur.

\section{Kaynakça}

Bayat, Ali H. (1998). Hüseyinzâde Ali Bey. Ankara: Atatürk Kültür Merkezi Başkanlığı Yayınları.

Best, Otto F. (1987). Handbuch Literarischer Fachbegriffe, Definitionen und Beispiele, (8. Auflage), Frankfurt am Main: Fischer Taschenbuch Verlag.

Birdwood-Hedger, Maya. (2006). Tension Between Domestication and Foreignization in EnglishLanguage Translations of Anna Karenina, (Doctor of Philosophy/Yayınlanmamış Doktora Tezi), University of Edinburgh.

Burçoğlu Kuran, Nedret. (2010). Çeviriye Bilimsel Yaklaşımlar. İstanbul: Multilingual.

Hatim, Basil. (2014). Teaching and Researching Translation, (Second Edition), New York: Routledge.

Hüseyinzade Ali. (1923). Kefalet Yahud Vefadar Dostlar, F. Schiller'den Nazmen Tercümedir, İstanbul: Kader Matbaası.

Hüseyinzade Ali. (1923). “Kefalet Yahud Vefadar Dostlar”, içinde İçtihad. (no. 159), (ss. 3265-3266).

Janet, Paul ve Séailles Gabriel. (1978). Metalib ve Mezahib. (Çev. Elmalı'lı M. Hamdi Yazır), (2. Baskı). İstanbul: Eser Neşriyat ve Dağıtım.

Karataş, Turan. (2018). Ansiklopedik Edebiyat Terimleri Sözlüğü. İstanbul: İz Yayıncılık. 
Koller, Werner. (2011). Einführung in die Übersetzungswissenschaft, (8. Auflage). Tübingen: A. Francke Verlag.

Paşayeva, G. ve Turan, A. (2014). Ali Bey Hüseyinzâde Turan. İstanbul: Şen Yıldız Yayıncılık.

Pons Großwörterbuch Deutsch als Fremdsprache. (2008). Stuttgart: Ernst Klett Sprachen GmbH.

Rasonyi, Laszlo. (1971). Tarihte Türklük, (Türkçe çeviri), Ankara: Türk Kültürünü Araştırma Enstitüsü (TKAE).

Schiller, Friedrich von. (1959). Balad'lar ve Şïrler. (Çev. Burhanettin Batıman), İstanbul: İstanbul Matbaasi.

Soysal, Firat. (2012). “Werner Koller'in Eşdeğerlik Simılandırmasına Farkh Bir Yaklaşım”, içinde Proceedings Book of Uluslararası Dil ve İletişim Sempozyumu: Araştırma Eğilimleri ve Güçlükler. Erzurum: Mega Press. (ss. 1419-1432).

Soysal, Frrat. (2012). Eşdeğerlik ve Skopos Kuramını Çeviri Eylemine Uygulanabilirlikleri: Bertolt Brecht Çevirilerine Eleştirel Bir Yaklaşım. (Yayınlanmamış Yüksek Lisans Tezi), Sosyal Bilimler Enstitüsü, Selçuk Üniversitesi. Konya.

Steuerwald, Karl. (1998). Almanca-Türkçe Sözlük. İstanbul: ABC Kitapevi A.Ş.

Taş, Seda. (2017). “Kültürel Unsurların Çevirisi ve Çeviri Stratejileri”, içinde Humanitas, (5(10): (ss. 114), Erişim: http://humanitas.nku.edu.tr. (Doi: 10.20304/humanitas.289303).

Tian, Chuanmao. (2010). "Etymological Implications of Domestication and Foreignization: A Chinese Perspective", içinde Perspectives: Studies in Translatology, (vol. 18: 2), (ss. 79-93), Routledge. (Doi: 10.1080/09076761003632541).

Türk Ansiklopedisi. (1983). (C. XXXII), M.E.B. Devlet Kitapları. Ankara: Milli Eğitim Basımevi.

Uca, Alaattin. (2017). İttihat ve Terakki Cemiyeti Kurucularından Türkçülük Fikrinin Ünlü Mütefekkiri Ali Bey Hüseyinzade (Turan) Hayatı Fikirleri ve Eserleri. Konya: Kömen Yayınları.

Venuti, Lawrence. (1995). Translator's Invisibility: A History of Translation. London and New York: Routledge.

Venuti, Lawrence. (1998). The Scandals of Translation: Towards an Ethics of Difference. London and New York: Routledge.

Venuti, Lawrence. (2004). Translator's Invisibility: A History of Translation, (e-Library), London and New York: Routledge.

Wahrig-Burfeind, Renate (ed.). (1998). Wahrig Wörterbuch der deutschen Sprache. (2. Aufl.), München: Deutscher Taschenbuch Verlag.

Wilpert, Gero von. (1979). Sachwörterbuch der Literatur, (erw. 6. Auflage), Stuttgart: Alfred Kröner Verlag.

Yang, Wenfen. (2010). "Brief Study on Domestication and Foreignization in Translation", içinde Journal of Language Teaching and Research, (Vol. 1, No. 1, ss. 77-80), Finland: Academy Publisher. (Doi:10.4304/jltr.1.1.77-80).

\section{İnternet kaynakları}

http://edebiyatsultani.com/bati-edebiyatindan-alinan-nazim-sekilleri/ (Erişim Tarihi: 20.07.2019).

http://ozhanozturk.com/2019/o2/11/sicilyanin-yunan-tarihi-ve-syracuse-sirakuza-kenti/(Erişim tarihi: 12.11.2019).

http://sozluk.gov.tr/ (Erişim Tarihi: 15.07.2019)

http://users.unimi.it/dililefi/costazza/programmi/2006-07/Schleiermacher.pdf (Erişim Tarihi: 20.07.2019).

https://gezimanya.com/sirakuza (Erişim Tarihi: 11.11.2019). 
https://medium.com/@natamadergi/bir-tan\%C4\%B1t\%C4\%B1m-dil-\%C5\%9Fiiri-l-a-n-g-u-a-g-epoetry-a6c5bocb597c. (Erişim Tarihi: 15.12.2019).

https://wortwuchs.net/ballade/ (Erişim Tarihi: 19.07.2019).

https://www.dict.cc/?s=erw\%C3\%BCrgen (Erişim Tarihi: 02.10.2019).

https://www.friedrich-schiller-archiv.de/inhaltsangaben/schiller-die-buergschaft-inhaltsangabeinterpretation-und-quelle/. (Erişim Tarihi: 10.12.2019).

https://www.mein-lernen.at/component/content/article?id=3171:ballade-die-buergschaft-friedrichschiller. (Erişim Tarihi: 12.12.2019).

https://www.turkedebiyati.org/balat.html. (Erişim Tarihi: 20.07.2019). 